\title{
Effects of shortening the close-up period length coupled with increased supply of metabolizable protein on performance and metabolic status of multiparous Holstein cows
}

\author{
T. Amirabadi Farahani, ${ }^{* 1}$ H. Amanlou, ${ }^{*}$ and M. Kazemi-Bonchenari† \\ *Department of Animal Science, University of Zanjan, Zanjan 45371-38791, Iran \\ †Department of Animal Science, Faculty of Agriculture and Natural Resources, Arak University, 38 156-8-8349, Arak, Iran
}

\begin{abstract}
This experiment was conducted to compare conventional (CON; $21 \mathrm{~d})$ and shortened $(\mathrm{SH} ; 10 \mathrm{~d})$ close-up period, and evaluate the effect of shortened close-up period combined with feeding different metabolizable protein (MP) levels on dry matter (DM) intake, metabolic status, and performance of dairy cows. Forty-eight multiparous Holstein cows with similar parity, body weight (BW), and previous lactation milk yield were divided into 2 groups. The first group $(\mathrm{n}=24)$ received the far-off diet from -60 to $-21 \mathrm{~d}(\mathrm{CON})$, and the second group $(\mathrm{n}=24)$ received same far-off diet from -60 to $-10 \mathrm{~d}(\mathrm{SH})$ relative to expected parturition. Cows were then moved to individual stalls and randomly allocated to 1 of 3 close-up diets: low MP diet (LMP; MP $=79 \mathrm{~g} / \mathrm{kg}$ of DM), medium MP $\operatorname{diet}(\mathrm{MMP} ; \mathrm{MP}=101$ $\mathrm{g} / \mathrm{kg}$ of DM), or high MP diet (HMP; MP $=118 \mathrm{~g} /$ $\mathrm{kg}$ of DM). Treatments were used in a $2 \times 3$ factorial arrangement with 2 lengths of close-up period (CON and SH) and 3 levels of MP (LMP, MMP, and HMP). All diets were fed for ad libitum intake during the closeup period. After calving, all cows received the same fresh cow diet. We found no interaction between closeup period length and MP levels for traits, except for postpartum serum fatty acids and $\beta$-hydroxybutyrate (BHB). The concentrations of postpartum serum fatty acids and BHB were higher on LMP than MMP and HMP diets in $\mathrm{SH}$ group. The cows of the $\mathrm{SH}$ group tended to produce less colostrum in the first milking than cows in CON group. The length of close-up period did not affect pre- and postpartum DM intake or energy balance of cows during the last week of prepartum, but cows of the CON group had greater BW changes during the last 3 wk before parturition than cows in $\mathrm{SH}$ group. Cows fed MMP and HMP diets consumed 1.2 and $1 \mathrm{~kg}$ more DM than for those fed LMP pre-
\end{abstract}

\footnotetext{
Received November 6, 2016.

Accepted February 22, 2017.

${ }^{1}$ Corresponding author: T.Farahani@znu.ac.ir
}

partum, respectively. The concentrations of prepartum BHB and Ca were higher for SH cows than CON group cows. Except for blood urea N concentration, no other blood metabolite in prepartum was affected by dietary MP. We found no effects of close-up period length or MP levels in the close-up diet on urinary $\mathrm{pH}$, purine derivative excretion, and microbial $\mathrm{N}$ flow. Postpartum, milk yield was not affected by close-up period length, but cows in CON group tended to have higher $4 \%$ fatcorrected milk yield, had higher milk fat content and yield, had greater BW and body condition score loss, and higher energy negative balance than cows in the $\mathrm{SH}$ group. Cows fed MMP diet ate $1.8 \mathrm{~kg}$ more DM and yielded $3.37 \mathrm{~kg}$ more milk than those fed the LMP diet. Milk fat, protein, and lactose content, milk urea N, and somatic cell count were not affected by MP levels, but the yield of milk protein and lactose were higher on MMP diet than on LMP diet. Concentrations of postpartum serum fatty acids and BHB were decreased by shortening the close-up period length, but glucose, cholesterol, and triglyceride were similar between closeup groups. During the postpartum period, serum fatty acids, BHB, aminotransferase, and $\mathrm{Ca}$ concentrations were decreased by increasing the MP levels in the closeup diet. It appears from this data set that multiparous cows will benefit from a shortened close-up period, and feeding a moderate MP diet could improve DM intake, milk yield, and metabolic status of periparturient dairy cows.

Key words: shortened close-up, metabolizable protein, metabolic status, periparturient cow

\section{INTRODUCTION}

The transition period is an extremely challenging period in the cow's productive cycle, where careful formulation of the diet can improve subsequent performance and health status (Lean et al., 2013). One of the tremendous challenges to successful adaptation in dairy cows is reduced DMI during the transition period (Lean et al., 2013). Feed intake is usually decreased 30 
to $35 \%$ during the last 3 wk before parturition (Grummer, 1995; Richards, 2011), and $89 \%$ of this decline happens in the last $7 \mathrm{~d}$ before calving (Hayirli et al., 2002). Grummer (1995) stated that prefresh feed intake was positively correlated with postcalving feed intake, and improving DMI during the prefresh period may have a significant effect on health and productivity after calving; therefore, strategies to maximize DMI should be initiated precalving (Grummer, 1995). These strategies included increasing the energy density of the diet during the entire dry period (Rabelo et al., 2003; Vickers et al., 2013; Mann et al., 2015) or the close-up period (Roche et al., 2015; Zhang et al., 2015), or limiting energy intake by restricted feeding in dry period (Dann et al., 2006; Douglas et al., 2006) or different days of exposure to close-up diet (Mashek and Beede, 2001; Robinson et al., 2001; DeGaris et al., 2008, 2010). Although, most studies conducted on increasing dietary energy density in the dry or close-up period reported an increase in prepartum DMI (Mann et al., 2015; Roche et al., 2015; Zhang et al., 2015), cows fed high-energy diets experienced an impaired metabolic status after calving. Despite the beneficial effects reported from limited feeding in prepartum cows on DMI and energy status during postpartum period (Dann et al., 2006; Douglas et al., 2006), restriction of feed intake is not recommended on commercial dairy farms with group housing systems because of increased competition at the feed bunk, which intensifies the decrease in feed intake (Overton and Waldron, 2004; Dann et al., 2006; Mann et al., 2015).

In studies with varied days of close-up period, feeding a close-up diet for greater than 3 wk increased the incidence of displaced abomasum and did not improve any productive parameters (Contreras et al., 2004). Mashek and Beede (2001) reported cows fed the closeup diet for an average of $37 \mathrm{~d}$ lost less BCS during the first 3 wk postpartum than cows fed for an average of $18 \mathrm{~d}$ prepartum, but tended to produce less milk during the first 180 DIM. Also, Robinson et al. (2001) found no benefit on productive and reproductive performance when feeding a close-up diet to multiparous cows. In addition, in a study with 13,000 cows that compared a close-up period $>21 \mathrm{~d}$ with $<7 \mathrm{~d}$, first test-day milk yield and peak milk yield were similar between the 2 groups (Corbett, 2002). However, none of aforementioned studies evaluated the effects of feeding duration of close-up diets on DMI and fluctuation of feed intake during the last week prepartum. Richards (2011) compared single- and 2-stage feeding strategies over the dry period. An interesting finding in Richards (2011) was the marked increase in DMI, with increased insulin and decreased serum fatty acid concentrations in the 2-stage cows when animals were switched from the far-off to close-up diet. However, these increases in DMI and energy balance only were maintained during the first week after the change. Therefore, it appears shortening the length of close-up period might be a beneficial strategy to increase DMI during the final days before calving due to the switching of a far-off to close-up diet.

Higher demands for AA and glucose by gravid uterus and mammary gland combined with decreased DMI immediately before calving compromise nutrient balance and predispose the cow to periparturient disorders (Marquardt et al., 1977; Bell, 1995). Therefore, nutrient density of the diet must be increased to offset decreased DMI immediately before calving (Vandehaar et al., 1999).

A considerable volume of studies have evaluated the effect of prepartum protein feeding on performance and health of transition dairy cows (Vandehaar et al., 1999; Greenfield et al., 2000; Hartwell et al., 2000; Phillips et al., 2003; Adachi et al., 2006). However, most of these studies failed to obtain significant results from higher dietary protein prepartum on postpartum performance (Greenfield et al., 2000; Hartwell et al., 2000; Robinson et al., 2001; Doepel et al., 2002; Park et al., 2002). The primary reason for unsuccessful postpartum responses to prepartum protein is likely the use of $\mathrm{CP}$ to express the protein requirements (Bell et al., 2000), increasing RUP at the expense of RDP, which reduces the microbial protein yield and results in no improvement in intestinally delivered MP (Santos et al., 1998), feeding high-protein diets to cows during postpartum period covering the effect of protein inadequacy of prepartum diets (Bell et al., 2000), or some combination. Although most published articles did not report any positive response with higher prepartum dietary protein, field observations suggest that protein requirements of the cows during the close-up period exceed those recommended by NRC (2001). Given the variation of DMI in close-up cows, increasing MP content in excess of NRC (2001) recommendations may improve health status and performance of transition cows. The objective of our study was to evaluate different MP content in close-up diets on DMI, milk production, and blood metabolites in peripartum cows during conventional $(\mathbf{C O N})$ and shortened $(\mathbf{S H})$ close-up periods.

\section{MATERIALS AND METHODS}

\section{Feeding, Experimental Design, and Management of Cows}

The present study was conducted on a commercial dairy farm in Isfahan, Iran, from April to June 2015. The average ambient temperature was $18.6^{\circ} \mathrm{C}$ and aver- 
age relative humidity was $42.0 \%$ during the experiment. Fifty-four multiparous Holstein cows with similar parity $(3 \pm 0.7)$, BW $(710 \pm 39.2 \mathrm{~kg})$, and previous lactation milk yield $(12,319 \pm 112 \mathrm{~kg})$ were enrolled in the study $60 \mathrm{~d}$ before expected calving. During the far-off period, cows were assigned to 2 pens of 27 cows each. The pens were identical in size, bunk space, design, flooring, and water accessibility. All cows were groupfed a similar far-off diet (Table 1) for ad libitum intake once daily $(0930 \mathrm{~h})$. Cows in the first pen received the far-off diet from -60 to $-21 \mathrm{~d}$ relative to expected parturition $(\mathrm{CON})$, and those in the second pen received the far-off diet from $-60 \mathrm{t}$ o $-10 \mathrm{~d}$ relative to expected parturition ( $\mathrm{SH})$. Cows were then moved to individual stalls and randomly allocated to 1 of 3 close-up diets, low MP (LMP; MP $=79 \mathrm{~g} / \mathrm{kg}$ of DM), medium MP $($ MMP; MP $=101 \mathrm{~g} / \mathrm{kg}$ of DM), or high MP (HMP; $\mathrm{MP}=118 \mathrm{~g} / \mathrm{kg}$ of $\mathrm{DM}$ ), until parturition (Table 1 ). Three close-up diets were formulated (NRC, 2001) to contain equal energy and different levels of MP (79, 101 , and $118 \mathrm{~g} / \mathrm{kg}$ of DM), with CP content of 12,15 , and $18 \%$ of DM, respectively. All cows were fed closeup diets ad libitum twice a day at 0800 and $1600 \mathrm{~h}$ to achieve 5 to $10 \%$ orts. Treatments were arranged in a 2 $\times 3$ factorial with 2 lengths of close-up period ( $21 \mathrm{~d}$ as CON and $10 \mathrm{~d}$ as SH) and 3 levels of MP (LMP, MMP, and HMP). Cows were required to have at least $7 \mathrm{~d}$ of prepartum DMI data to remain on the study; thus, 6 cows with days fed the close-up diets less than $7 \mathrm{~d}$ were removed from the experiment ( 2 for early calving and one for abortion in CON group; 3 for early calving in $\mathrm{SH}$ group), and the actual days for remaining 48 cows in close-up diets ranged from 14 to $28 \mathrm{~d}(19 \pm 4.6)$ and 7 to $13 \mathrm{~d}(9.5 \pm 2.3)$ for CON and SH close-up periods, respectively.

As cows showed primary signs of calving, they were moved to maternity pens; calf weight and first- milking colostrum were recorded immediately postpartum by calving personnel. Wet placenta weight and time taken for placenta expulsion were also recorded. Calving difficulty score (CDS) was determined using a 5-point scale $(1=$ no calving problem, $2=$ minor problem, $3=$ needed assistance, $4=$ considerable force, $5=$ caesarian; Park et al., 2002). After that, cows were moved to individual stalls until 21 DIM with free access to water. All cows received the same fresh diet (Table 1) ad libitum thrice a day at 0900, 1700, and $2300 \mathrm{~h}$. The far-off, close-up, and fresh diets were fed as a TMR. Cows were milked 3 times a day at 0800, 1600, and $2200 \mathrm{~h}$.

\section{Sampling and Data Collection}

During the close-up period, DMI of individual cows was determined daily from $-10 \mathrm{~d}$ relative to expected calving until parturition. The DMI of individual animals was also recorded daily from calving until 21 DIM. Samples of TMR and orts were taken twice a week for $\mathrm{DM}$ measurement, dried at $60^{\circ} \mathrm{C}$ for $48 \mathrm{~h}$, and then composited by week and treatment. Individual feed ingredients were also sampled weekly and frozen at $-20^{\circ} \mathrm{C}$ for later analysis. Feed samples ground through a 1-mm screen and analyzed for Kjeldahl N (AOAC, 1990; method 984.13), ether extract (AOAC, 1990; method 920.39), ash (AOAC, 1990, method 942.05), ADF (AOAC, 1990; method 973.18), and NDF (Van Soest et al., 1991).

Cows were weighed at $-21,-10,-3,0$, and $21 \mathrm{~d}$ relative to calving, and $\mathrm{BW}$ loss due to calving was calculated as the BW before calving $(-3 \mathrm{~d})$ minus after calving weight (calving day). Cows were scored for body condition (Edmonson et al., 1989) by 2 skilled investigators at $-21,0$, and $21 \mathrm{~d}$ relative to calving. Results from the 2 investigators were averaged and used for analysis.

Milk yield of individual cows was recorded daily from 1 to 21 DIM. Milk samples from each cow were taken weekly from 3 consecutive milkings, composited in proportion to milk yield, and milk composition (fat, protein, lactose, SCC, and urea) determined by midinfrared spectroscopic procedure using a Milkoscan (CombiFoss 78110; Foss Analytical A/S, Hillerød, Denmark).

The equations of NRC (2001) were used to calculate energy balance (EB) in close-up and fresh periods. Net energy intake $\left(\mathrm{NE}_{\mathrm{I}}\right)$ was calculated by multiplying DMI by megacalories of $\mathrm{NE}_{\mathrm{L}}$ per kilogram of $\mathrm{DM}$. Net energy requirement for maintenance was calculated as $0.08 \times$ metabolic BW $\left(\mathrm{BW}^{0.75}\right)$. Net energy requirement for pregnancy $\left(\mathrm{NE}_{\mathrm{P}}\right)$ was calculated as $[(0.00318 \times$ day of gestation -0.0352$) \times($ calf birth weight/45)]/0.218 Net energy requirement for lactation was calculated as $(0.0929 \times$ fat $\%+0.0563 \times$ protein $\%+0.0395 \times$ lactose $\%) \times$ milk yield. The close-up $\mathrm{EB}\left(\%\right.$ of $\mathrm{NE}_{\mathrm{L}}$ requirement) was calculated as $\mathrm{EB}=\left[\mathrm{NE}_{\mathrm{I}} /\left(\mathrm{NE}_{\mathrm{M}}+\right.\right.$ $\left.\left.\mathrm{NE}_{\mathrm{P}}\right)\right] \times 100$; postpartum EB was calculated as $\mathrm{EB}=$ $\left[\mathrm{NE}_{\mathrm{I}} /\left(\mathrm{NE}_{\mathrm{M}}+\mathrm{NE}_{\mathrm{L}}\right)\right] \times 100$.

Blood samples were taken $4 \mathrm{~h}$ after morning feeding from the coccygeal vein using an evacuated tube without anticoagulant (Vacumed no additive, FL Medical, Torreglia, Italy) at $-21,-10,-7,-3,-1,0,3$, 7, 14 and $21 \mathrm{~d}$ relative to expected parturition; actual days of blood sampling in prepartum were adjusted for target days. Serum samples were collected following centrifugation at $2,500 \times g$ for $10 \mathrm{~min}$ at $20^{\circ} \mathrm{C}$, and were stored at $-20^{\circ} \mathrm{C}$ for later analysis. Serum samples were analyzed for concentrations of glucose (glucose oxidase-phenol 4-aminoantipyrine peroxidase method), albumin (bromocresol green method at acidic $\mathrm{pH}$ ), to- 
tal protein (biuret method), BUN (berthelot method), aspartate aminotransferase (AST; IFCC method), cholesterol (cholesterol oxidase-phenol 4-aminoantipyrine peroxidase method), triacylglycerol (TAG; glycerol-3-phosphate oxidase-phenol 4 aminoantipyrine peroxidase method), total Ca (O-Cresolphthalein-complexone method), and Mg (Xylidyl blue method) using commercial kits (Pars Azmoon Laboratory, Tehran, Iran). Serum concentrations of fatty acids (colorimetric method) and BHB (Enzymatic method; based on 3-hydroxybutyrate dehydrogenase) were measured by Randox Kits (Randox Laboratories Ltd., Crumlin, UK), using a serum spectrophotometer (UNICCO, 2100, Zistchemi Co., Tehran, Iran). All of the serum metabolites were analyzed according to references from
Amanlou et al. (2016, 2017). Globulin concentration was obtained as the difference between total protein and albumin.

Spot urine samples (100 mL per sampling) were collected 3 times daily at 1100, 1500, and $1900 \mathrm{~h}$ on d -5 , and 0900,1300 , and $1700 \mathrm{~h}$ on $\mathrm{d}-3$ relative to calving. To monitor the efficacy of DCAD program, urine samples obtained from each cow were immediately analyzed for $\mathrm{pH}$ using a $\mathrm{pH}$ meter (HI8318; Hanna Instruments, Cluj-Napoca, Romania), and then acidified with $2 \mathrm{M} \mathrm{H}_{2} \mathrm{SO}_{4}$ to $\mathrm{pH}<3.0$, diluted with distilled water $(1: 10)$, and stored at $-20^{\circ} \mathrm{C}$ for subsequent analysis (Lee et al., 2012). After thawing, acidified urine samples were composited by cow and treatment and analyzed for allantoin (Young and Con-

Table 1. Feed ingredients of the diets fed during far-off, close-up, and fresh periods (\% of DM)

\begin{tabular}{|c|c|c|c|c|c|}
\hline \multirow[b]{2}{*}{ Ingredient } & \multirow[b]{2}{*}{ Far-off } & \multicolumn{3}{|c|}{ Close-up ${ }^{1}$} & \multirow[b]{2}{*}{ Fresh } \\
\hline & & LMP & MMP & HMP & \\
\hline Legume forage hay, mature $^{2}$ & 26.80 & 18.76 & 18.76 & 18.76 & 20.30 \\
\hline Corn silage, normal $^{3}$ & 44.27 & 41.00 & 41.00 & 41.00 & 25.50 \\
\hline Barley grain, rolled ${ }^{4}$ & 5.00 & 8.00 & 5.00 & 2.00 & 11.00 \\
\hline Corn grain, ground, dry ${ }^{5}$ & 5.00 & 15.45 & 12.50 & 9.55 & 16.85 \\
\hline Cottonseed, whole with lint ${ }^{6}$ & - & 5.0 & 5.0 & 5.0 & 6.60 \\
\hline Canola meal, mechanical extraction ${ }^{7}$ & 4.33 & 1.60 & 1.60 & 1.60 & - \\
\hline Soybean meal, solvent ${ }^{8}$ & 4.00 & 6.00 & 6.00 & 6.00 & 9.50 \\
\hline Fish meal $^{9}$ & - & - & 3.00 & 6.00 & 1.11 \\
\hline Corn gluten meal ${ }^{10}$ & - & - & 3.00 & 6.00 & 1.00 \\
\hline Extruded full-fat soybean ${ }^{11}$ & - & - & - & - & 4.50 \\
\hline Rice bran & 8.90 & - & - & - & - \\
\hline Salt & 0.21 & - & - & - & 0.30 \\
\hline Calcium carbonate & 0.53 & 1.35 & 1.35 & 1.35 & 0.67 \\
\hline Dicalcium phosphate & 0.11 & - & - & - & 0.30 \\
\hline Magnesium oxide & 0.11 & 0.15 & 0.15 & 0.15 & 0.24 \\
\hline Magnesium sulfate & - & 0.85 & 0.80 & 0.75 & - \\
\hline Calcium chloride & - & 0.45 & 0.45 & 0.45 & - \\
\hline Bentonite & 0.32 & 0.47 & 0.47 & 0.47 & 0.33 \\
\hline Biotin & - & 0.004 & 0.004 & 0.004 & 0.004 \\
\hline Selenium & - & 0.004 & 0.004 & 0.004 & 0.004 \\
\hline Choline chloride & - & 0.37 & 0.37 & 0.37 & 0.24 \\
\hline Monensin & - & 0.01 & 0.01 & 0.01 & 0.01 \\
\hline $\mathrm{NaHCO}_{3}$ & - & - & - & - & 1.10 \\
\hline Mineral premix ${ }^{12}$ & 0.21 & 0.27 & 0.27 & 0.27 & 0.23 \\
\hline Vitamin premix $^{13}$ & 0.21 & 0.27 & 0.27 & 0.27 & 0.23 \\
\hline
\end{tabular}

${ }^{1} \mathrm{LMP}=$ low MP, MMP $=$ medium MP, HMP = high MP containing 79, 101, and $118 \mathrm{~g} / \mathrm{kg}$ of DM of MP, respectively.

${ }^{2}$ Contained $83.0 \%$ DM, $51.0 \% \mathrm{NDF}, 39.6 \% \mathrm{ADF}$, and 13.5\% CP (DM basis).

${ }^{3}$ Contained $23.0 \%$ DM, $45.0 \% \mathrm{NDF}, 29 \% \mathrm{ADF}$, and $8.5 \% \mathrm{CP}$ (DM basis).

${ }^{4}$ Contained $11.7 \%$ CP (DM basis).

${ }^{5}$ Contained $8.4 \%$ CP (DM basis).

${ }^{6}$ Contained $90.0 \%$ DM, 51.4\% NDF, 40.0\% ADF, and 20.3\% CP (DM basis).

${ }^{7}$ Contained $37.8 \% \mathrm{CP}$ (DM basis).

${ }^{8}$ Contained $42.0 \%$ CP (DM basis).

${ }^{9}$ Contained $55.0 \% \mathrm{CP}$ (DM basis).

${ }^{10}$ Contained $56.0 \% \mathrm{CP}$ (DM basis).

${ }^{11}$ Contained $38.0 \%$ CP (DM basis).

${ }^{12}$ Premix contained $0.32 \mathrm{~g}$ of $\mathrm{Co} / \mathrm{kg}, 13.3 \mathrm{~g}$ of $\mathrm{Cu} / \mathrm{kg}, 0.5 \mathrm{~g}$ of I/ $\mathrm{kg}, 0.04 \mathrm{~g}$ of Fe $/ \mathrm{kg}, 33.4 \mathrm{~g}$ of $\mathrm{Mn} / \mathrm{kg}, 8 \mathrm{~g}$ of $\mathrm{Se} / \mathrm{kg}$, and $56.2 \mathrm{~g}$ of $\mathrm{Zn} / \mathrm{kg}$.

${ }^{13}$ Premix contained 1,800,000 IU of vitamin A/kg, 200,000 IU of vitamin D/kg, and 15,000 IU of vitamin E/ $\mathrm{kg}$. 
way, 1942), uric acid (enzymatic colorimetric uricase method), and creatinine (enzymatic Jaffe method). Urinary creatinine concentration and $\mathrm{BW}$ were used to determine daily urine volume as $29(\mathrm{mg} / \mathrm{kg}) \times \mathrm{BW}$ $(\mathrm{kg}) \times[1 /$ urinary creatinine $(\mathrm{mg} / \mathrm{L})]$ (Valadares et al., 1999). Endogenous purine derivative (PD; allantoin and uric acid) excretion $(\mathrm{mmol} / \mathrm{d})$ was estimated as $0.385 \mathrm{mmol} / \mathrm{BW}^{0.75}$ per day (Chen and Gomes, 1992). Duodenal microbial $\mathrm{N}$ flow was calculated from urinary PD excretion (Chen and Gomes, 1992).

\section{Statistical Analyses}

Data were analyzed as a completely randomized design with a $2 \times 3$ factorial arrangement of treatments (the length of close-up period $\times$ MP levels). At -21 $\mathrm{d}$ relative to expected calving date, pervious lactation milk yield and BW were evaluated across all treatment groups using the general linear models procedure of SAS (PROC GLM; version 9.3, SAS Institute Inc., Cary, NC). Generalized linear mixed models (PROC GLIMMIX) was used to study the proportion of cows in each treatment group for parity $(2$ or $\geq 3)$ and BCS $(\leq 3.25,3.5$, and $\geq 3.75)$. To avoid problems with fitting covariance structure, close-up and postpartum period data were analyzed separately. Repeated measures data were analyzed using PROC MIXED of SAS. The statistical model included the fixed effects of close-up period length, MP levels, sampling time (days to calving for prepartum data and week and DIM for postpartum data), and the interactions of close-up period length and MP levels, time and close-up period length, time and MP levels, time and close-up period length and MP levels, and random effect of cow within treatment (error term). On the basis of the smallest Bayesian information criterion, Akaike information criterion, and corrected Akaike information criterion, the most appropriate covariance structure were used for each variable analyzed (Littell et al., 1998). Using this procedure, the autoregressive covariance structure was the best fit for data in the current experiment. For analyzing calf weight, CDS, placenta weight, time for placenta expulsion, $\mathrm{BCS}$ and $\mathrm{BW}$ changes, urine $\mathrm{pH}$, and urinary $\mathrm{PD}$ excretion, the fixed effects of time and their interactions were excluded from the ANOVA model. Previous lactation yield, parity, BW, and the concentrations of serum metabolites obtained at $-21 \mathrm{~d}$ relative to expected calving date were used as covariates and covariates were excluded from the model if they were not significant $(P>0.1)$. Data are reported as LSM and statistical significances were declared at $P \leq 0.05$ and $0.05<P \leq 0.10$ as trends toward significance using the Tukey's multiple comparison test.

\section{RESULTS AND DISCUSSION}

\section{Diet Composition}

In our experiment, the far-off diet contained 1.59 Mcal of $\mathrm{NE}_{\mathrm{L}} / \mathrm{kg}$ and $13 \% \mathrm{CP}$ (DM basis; Table 2). All close-up diets (Table 1) were formulated to contain 1.6 Mcal of $\mathrm{NE}_{\mathrm{L}} / \mathrm{kg}$ of DM (Table 2). The diets varied in NFC content $[100-(\mathrm{NDF}+$ fat + protein + ash $)]$ from $43.0 \%$ for the LMP diet to $37.8 \%$ DM for the HMP diet because corn gluten meal and fish meal (as RUP sources) were substituted for barley and corn to reach increased amounts of dietary protein (Table 1 ). Protein supplies and their balances in the close-up and fresh diets were estimated using NRC (2001) by actual individual cow DMI, BW, BCS, and calf weight, milk yield, and milk composition and based on actual chemical composition of individual feed ingredients (Table 2 ). The LMP diet supplied $849 \mathrm{~g} / \mathrm{d}$ of MP to the cows according to the guidelines of NRC (2001) model, whereas MMP and HMP diets supplied MP in excess of NRC (2001) recommendations, at 1,200 and 1,387 $\mathrm{g} / \mathrm{d}$ of MP, respectively.

\section{Calving Measurements}

At -21 d relative to expected calving date, no differences were found in the proportions of cows with parity 2 or $\geq 3(P=0.99)$, BCS $\leq 3.25,3.5$, or $\geq 3.75$ $(P>0.1)$, average previous lactation milk yield $(P=$ $0.33)$, and BW $(P=0.92)$ across treatments (Table 3$)$. Calf birth weight did not differ between the length of close-up period $(P=0.16$; Table 4$)$, among MP levels in the close-up diet $(P=0.16$; Table 4$)$, or regarding the close-up $\times$ MP interaction $(P=0.89$; Table 4$)$. Similarly, other researchers found no effect of prepartum protein feeding on calf birth weight (Van Saun, 1993; Doepel et al., 2002; Park et al., 2002). We noted no effects $(P>0.10)$ of the close-up period length, MP levels in close-up diet, and close-up length $\times$ MP interactions on CDS, wet placenta weight, and time for placenta expulsion (Table 4), which is in agreement with Adachi et al. (2006). Contrary to our results, Park et al. (2002) reported that CDS was higher in cows fed 9.7 and $11.7 \% \mathrm{CP}$ diets than cows fed higher CP diets. These inconsistent results may be related to the fact their experimental diets were contained less than $12 \%$ CP. A trend was observed for cows assigned to CON group to produce more colostrum in the first milking $(P$ $=0.08$ ) than cows in SH group (Table 4). In agreement with the findings of Hook et al. (1989), level of MP in close-up diet did not affect colostrum volume $(P=$ 0.60; Table 4). Losses in BW and BCS at calving were not different $(P>0.10)$ between the length of close-up 
Table 2. Chemical composition of the diets fed during far-off, close-up, and fresh periods (\% of DM, unless otherwise stated)

\begin{tabular}{|c|c|c|c|c|c|}
\hline \multirow[b]{2}{*}{ Component } & \multirow[b]{2}{*}{ Far-off } & \multicolumn{3}{|c|}{ Close-up ${ }^{1}$} & \multirow[b]{2}{*}{ Fresh } \\
\hline & & LMP & MMP & HMP & \\
\hline $\mathrm{NE}_{\mathrm{L}}(\mathrm{Mcal} / \mathrm{kg}$ of $\mathrm{DM})$ & 1.59 & 1.6 & 1.6 & 1.6 & 1.68 \\
\hline $\mathrm{CP}$ & 13.0 & 12.4 & 15.1 & 18.0 & 16.00 \\
\hline RDP & 9.2 & 9.1 & 10 & 11 & 11.00 \\
\hline RUP & 3.8 & 3.3 & 5.1 & 7 & 5.00 \\
\hline $\mathrm{MP}(\mathrm{g} / \mathrm{kg}$ of $\mathrm{DM})$ & 82 & 79 & 101 & 118 & 103 \\
\hline NDF & 39.3 & 35 & 34.4 & 33.8 & 31.3 \\
\hline Forage NDF & 33.5 & 28 & 28 & 28 & 21.6 \\
\hline $\mathrm{ADF}$ & 26.0 & 23 & 23 & 23 & 20.8 \\
\hline $\mathrm{NFC}$ & 38.7 & 43 & 40.5 & 37.8 & 42.3 \\
\hline Ether extract & 3.8 & 3.6 & 3.6 & 3.6 & 4.4 \\
\hline $\mathrm{Ca}$ & 0.7 & 1.1 & 1.2 & 1.3 & 0.8 \\
\hline $\mathrm{P}$ & 0.4 & 0.33 & 0.36 & 0.39 & 0.36 \\
\hline $\mathrm{Mg}$ & 0.3 & 0.4 & 0.4 & 0.4 & 0.35 \\
\hline $\mathrm{Na}$ & 0.10 & 0.02 & 0.05 & 0.08 & 0.45 \\
\hline K & 1.51 & 1.25 & 1.27 & 1.28 & 1.3 \\
\hline $\mathrm{Cl}$ & 0.41 & 0.47 & 0.48 & 0.49 & 0.41 \\
\hline S & 0.20 & 0.36 & 0.39 & 0.42 & 0.21 \\
\hline DCAD $(\mathrm{mEq} / \mathrm{kg}$ of $\mathrm{DM})$ & 190 & -28 & -31 & -37 & 282 \\
\hline \multicolumn{6}{|l|}{ Protein supply $^{2}(\mathrm{~g} / \mathrm{d})$} \\
\hline RDP supply & 1,200 & 971 & 1,187 & 1,294 & 1,918 \\
\hline RDP balance & -112 & -128 & -29 & +98 & +132 \\
\hline RUP supply & 494 & 347 & 602 & 803 & 860 \\
\hline RUP balance & +379 & +55 & +429 & +628 & -735 \\
\hline MP supply & 1,075 & 849 & 1,200 & 1,387 & 1,770 \\
\hline MP requirements ${ }^{3}$ & 798 & 926 & 965 & 974 & 2,382 \\
\hline MP balance & +276 & -77 & +235 & +413 & -612 \\
\hline
\end{tabular}

${ }^{1} \mathrm{LMP}=$ low MP, MMP $=$ medium MP, HMP = high MP containing 79, 101, and $118 \mathrm{~g} / \mathrm{kg}$ of DM of MP, respectively.

${ }^{2}$ NRC (2001) model was used to estimate protein supplies and their balances based on actual individual cow DMI, BW, BCS, and calf weight for close-up period; and based on actual individual cow DMI, BW, BCS, and calf weight, milk yield, and milk composition for fresh period.

${ }^{3}$ Requirement was NRC model plus $120 \mathrm{~g}$ of MP to account for mammary growth (Bell et al., 2000).

period, among the levels of MP in close-up diet, or for close-up length $\times$ MP interaction (Table 4 ).

\section{Close-Up Period}

$\boldsymbol{D} M I, \boldsymbol{E} B$, and $\boldsymbol{B} \boldsymbol{W}$. Effects of close-up period length, MP levels in the close-up diet, and close-up length $\times$ MP interaction on DMI, EB, and BW are presented in Table 5 . The length of close-up period did not affect DMI, net energy intake, and EB of cows during the last $7 \mathrm{~d}$ of prepartum $(P>0.10$; Table 5$)$. However, we did note an effect of day $(P<0.01)$ and a tendency $(P=0.06)$ for a close-up length $\times$ day interaction on DMI during the last $7 \mathrm{~d}$ of gestation (Figure 1A); thus, cows assigned to the CON group had greater DMI depression than cows in the SH group (31 vs. 17\%).

Although our primary objective of shortening close-up period length was to increase DMI during the final days before calving due to switching far-off to close-up diets, DMI was similar between the CON and SH groups. Regardless of a lack of difference in DMI prepartum, cows assigned to the SH group showed less DMI variation during the last $7 \mathrm{~d}$ before parturition compared with cows in CON group $(11.46 \pm 1.9$ vs. $11.31 \pm 2.7 \mathrm{~kg} / \mathrm{d})$ and maintained DMI at more consistent level until the day before calving (Figure 1A).

The variation in DMI has likely more substantial effects on metabolic status of transition cows than the amount of feed intake (Grummer et al., 2004). Our observation is in agreement with the findings of Mann et al. (2015), who reported feeding a far-off diet during the entire dry period led to fewer changes in prepartum DMI than feeding a 2-stage diet (controlled-energy faroff diet and higher-energy close-up diet). Nevertheless, most dairies tend to increase exposure to close-up diets because of uncertainty of calving time. To our knowledge, the present study is the first work in close-up cows to consider the effect of close-up period length on DMI in the last days of prepartum. Therefore, the reason for less variation in prepartum DMI in SH group is unknown.

Cows fed MMP and HMP prepartum diets consumed more DMI $(P=0.01)$ than cows fed the LMP diet (Table 5). Energy balance tended $(P=0.07)$ to 
be higher for cows fed MMP and HMP diets (121.8 and $125.7 \%$ of $\mathrm{NE}_{\mathrm{L}}$ requirement, respectively) than for those fed LMP (112.0\% of $\mathrm{NE}_{\mathrm{L}}$ requirement). Unlike results of the present study, more studies supplementing protein in close-up diets have observed no effect on prepartum DMI (Huyler et al., 1999; Greenfield et al., 2000; Doepel et al., 2002; Park et al., 2002). In the aforementioned studies, the lack of response in prepartum DMI to increase dietary protein may be a result of gut fill from higher NDF (Allen, 2000) in low-energy diets or inadequate RDP supply to meet microbial needs, resulting not only in a reduction in MP but also a reduction in fiber digestibility (Santos et al., 1998). This was supported by Hayirli et al. (2002), who reported feeding diets containing more than $9 \%$ RDP and less than 39.9\% NDF maximized microbial protein flow from the rumen. Vandehaar et al. (1999) reported that cows fed diets with high energy and high protein $\left(1.61 \mathrm{Mcal} / \mathrm{kg}\right.$ of $\mathrm{NE}_{\mathrm{L}}$ and $15.9 \% \mathrm{CP}$ ) consumed $14 \%$ more DM and $40 \%$ more energy than the cows fed low-energy, low-protein diets $\left(1.30 \mathrm{Mcal} / \mathrm{kg}\right.$ of $\mathrm{NE}_{\mathrm{L}}$ and $12.2 \%$ CP). Emery (1993) also observed a $30 \%$ increase in DMI as the density of both energy (1.54 vs. 1.30 Mcal of $\mathrm{NE}_{\mathrm{L}} / \mathrm{kg}$ of $\mathrm{DM}$ ) and protein (16.0 vs. $13.0 \%$ $\mathrm{CP})$ were increased during the last $3 \mathrm{wk}$ prepartum. These studies support our results for increased DMI with supplementing protein in high-energy diets. In another study (Phillips et al., 2003), increasing dietary CP from 11.4 to $15.6 \%$ CP did not improve DMI during the last 3 wk prepartum, but feed intake increased relative to prior intake during the last week prepartum with higher-CP diets.

Mean BW and BW change during the last 3 wk before parturition were influenced by close-up period length $(P<0.05$; Table 5$)$ but not by MP levels $(P>0.10)$, where cows in CON group had greater BW gain (17.4 vs. $12.5 \mathrm{~kg}$ ) than cows in $\mathrm{SH}$ group, as expected with longer exposure to close-up diet. Other research investigating effects of close-up period length on performance and health (Mashek and Beede, 2001; Robinson et al., 2001; Contreras et al., 2004) did not report any data on BW changes. However, studies conducted on feeding controlled-energy diet during the close-up period (Dann et al., 2006) found that cows fed ad libitum diets gain more weight during the close-up period compared with cows fed restricted diets, which is in agreement with our findings.

Blood Metabolites. No interaction of close-up period length by levels of MP in close-up diet was detected for prepartum blood metabolites $(P>0.10$; Table 6$)$. Concentrations of total protein, albumin, globulin, and albumin-to-globulin ratio were not affected $(P>0.10)$ by close-up period length (Table 6 ). However, we did note a day effect $(P \leq 0.05)$ on serum total protein, 
and albumin, where their concentrations decreased as parturition approached (Table 6). Among the biomarkers related to energy metabolism (glucose, fatty acids, BHB), only prepartum BHB concentration was affected by the length of close-up period, with higher $(P=0.03)$ values in $\mathrm{SH}$ cows compared with $\mathrm{CON}$ cows $(0.50$ vs. $0.45 \mathrm{mmol} / \mathrm{L}$; Table 6). Serum concentrations of glucose, fatty acids, and BHB showed a usual pattern during the close-up period, with glucose decreasing $(P$ $<0.01)$, whereas fatty acids and BHB increased $(P<$ 0.01) with approaching calving (Table 6).

Although CON cows had a greater variation in DMI, they did not experience negative energy balance prepartum, which is consistent with serum fatty acids and glucose results. Dann et al. (2006) reported cows fed ad libitum during the last $7 \mathrm{~d}$ of gestation had greater changes in DMI than cows fed restricted intake, but they had lower concentrations of fatty acids ( 0.27 vs. $0.45 \mathrm{mmol} / \mathrm{L}$ ) in serum. In addition, previous studies reported no effects on serum fatty acid concentration during the prepartum period when close-up diets were fed for more than 3 wk (Mashek and Beede, 2001; Contreras et al., 2004). A similar BHB concentration with $\mathrm{CON}$ and $\mathrm{SH}$ would be expected given the serum fatty acid findings; however, BHB concentrations were increased by shortening the length of close-up period $(P=0.03$; Table 6$)$. Despite the statistical difference observed on BHB levels regarding to close-up period length, BHB concentrations of cows in our study were within the range reported by other researchers (Janovick et al., 2011; Zhang et al., 2015). Additionally, Ospina et al. (2010) found concentrations of prepartum fatty acids and postpartum fatty acids and BHB, but not prepartum BHB, to be important indexes to predict disorders incidence and evaluate health status of cows during transition period.

With the exception of BUN, concentrations of total protein, albumin, globulin, and albumin-to-globulin ratio were not affected $(P>0.10$; Table 6$)$ by MP levels in the close-up diet. In agreement with other studies (Greenfield et al., 2000; Hartwell et al., 2000; Doepel et al., 2002), cows fed MMP and HMP diets had increased BUN concentration during the prepartum period compared with those fed LMP $\operatorname{diet}(P<$ 0.01; Table 6), and BUN concentrations decreased in all diets with approaching calving $(P<0.01$; Table $6)$. This may indicate greater efficiency of AA use for maintenance and gestation, decreased protein intake, or both (Hartwell et al., 2000; Doepel et al., 2002). Increased BUN concentrations are a function of dietary $\mathrm{CP}$ content, ruminal protein degradability, and postruminal supply of protein (Jonker et al., 1998). Because cows in our experiment consumed different amounts of RDP and RUP ( $P<0.01$; Table 5$)$, the increased BUN concentrations in cows fed the MMP and HMP diets could be due to ruminal metabolism of protein and oxidation of AA absorbed in excess of requirements or both. Additionally, increased BUN concentrations with additional protein supply can be due to greater use of AA as an energy source by fetal tissues (Bell, 1995), which was supported by numerically higher calf birth weight $(43.19,44.36$, and $45.57 \mathrm{~kg}$ in LMP, MMP, and HMP, respectively) observed in the present study, though differences were not significant.

Levels of MP in the close-up diet did not affect any of the energy indexes during the prepartum period $(P$

Table 4. Effects of increasing MP supply in close-up diets on calving measurements for multiparous Holstein cows with conventional (CON) and shortened ( $\mathrm{SH})$ close-up periods

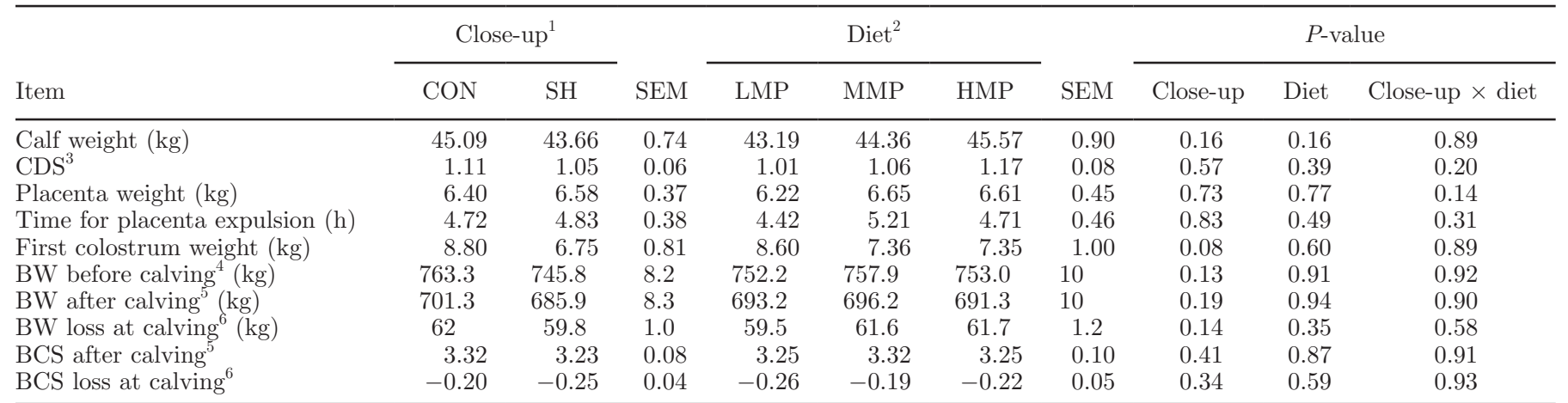

\footnotetext{
${ }^{1}$ The CON group was assigned to a close-up period of $19 \mathrm{~d}(\mathrm{SD}=4.6 \mathrm{~d})$ and the SH group was assigned to a close-up period of $9.5 \mathrm{~d}(\mathrm{SD}=2.3 \mathrm{~d})$. ${ }^{2} \mathrm{LMP}=$ low MP, MMP $=$ medium MP, HMP $=$ high MP containing 79, 101, and $118 \mathrm{~g} / \mathrm{kg}$ of DM of MP, respectively.

${ }^{3}$ Calving difficulty score (scale of 1 to 5 , where $1=$ no calving problem, $2=$ minor problem, $3=$ needed assistance, $4=$ considerable force, $5=$ caesarian; Park et al., 2002).

${ }^{4}$ Body weight taken at $-3 \mathrm{~d}$ before parturition.

${ }^{5}$ Body weight and BCS taken at calving day.

${ }^{6}$ The difference between the BW and BCS before and after calving.
} 
$>0.10$; Table 6). In agreement with our findings, previous studies (Greenfield et al., 2000; Santos et al., 2001; Adachi et al., 2006) observed similar fatty acid and BHB concentrations independent of prepartum protein levels. Neither cholesterol nor triglyceride concentration was affected by close-up period length or MP levels, but concentrations of both metabolites decreased with approaching calving $(P<0.01$; Table 6$)$.

Although, it has been suggested the length of feeding close-up diets is independent of dietary DCAD (Lean et al., 2006), we measured urinary $\mathrm{pH}$ to evaluate efficacy of anionic salts for cows fed different levels of protein in $\mathrm{SH}$ and $\mathrm{CON}$ close-up period. The urinary $\mathrm{pH}$ was similar between $\mathrm{SH}$ and $\mathrm{CON}$ groups $(P=0.42$; Table $6)$, with an average of $6.44 \pm 0.3$ showing an effective
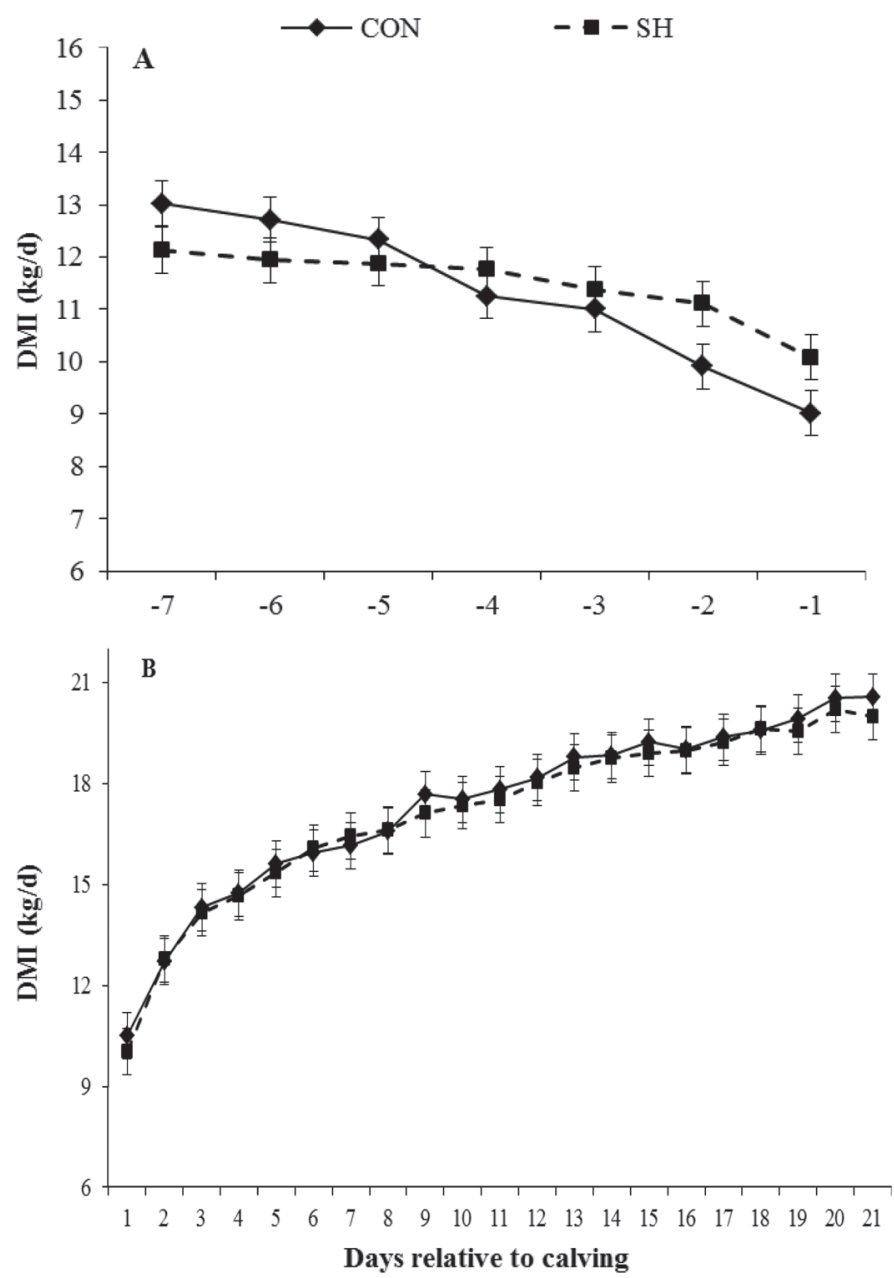

Figure 1. Dry matter intake $(\mathrm{kg}) \mathrm{d} 7$ to 1 prepartum (A) and d 1 to 21 postpartum (B) in cows assigned to a conventional (CON, $19 \pm 4.6$ d) or shortened close-up period ( $\mathrm{SH}, 9.5 \pm 2.3 \mathrm{~d})$. Data are presented as least squares means and SEM. Prepartum: close-up, $P=0.52$; diet, $P=0.01$; day, $P<0.01$; close-up $\times$ diet, $P=0.43$; close-up $\times$ day, $P$ $=0.06$; diet $\times$ day, $P=0.90$. Postpartum: close-up, $P=0.91$; diet, $P$ $\leq 0.01$; week, $P<0.01$; close-up $\times$ diet, $P=0.78$; close-up $\times$ week, $P$ $=0.70$; diet $\times$ week, $P=0.60$.

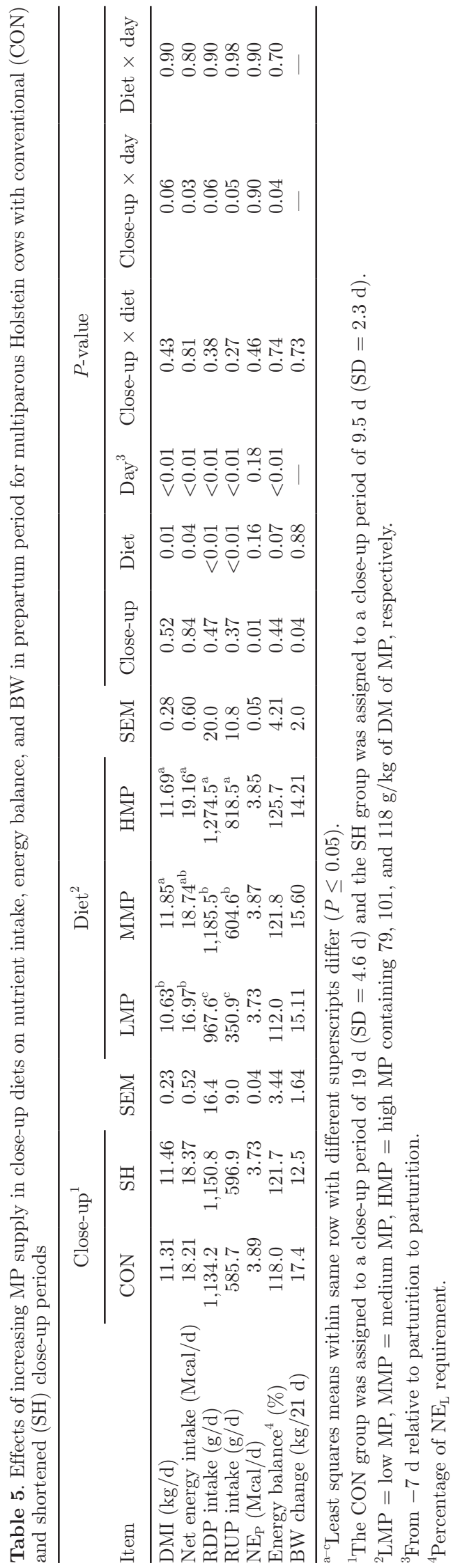

Journal of Dairy Science Vol. 100 No. 8, 2017 
FARAHANI ET AL.

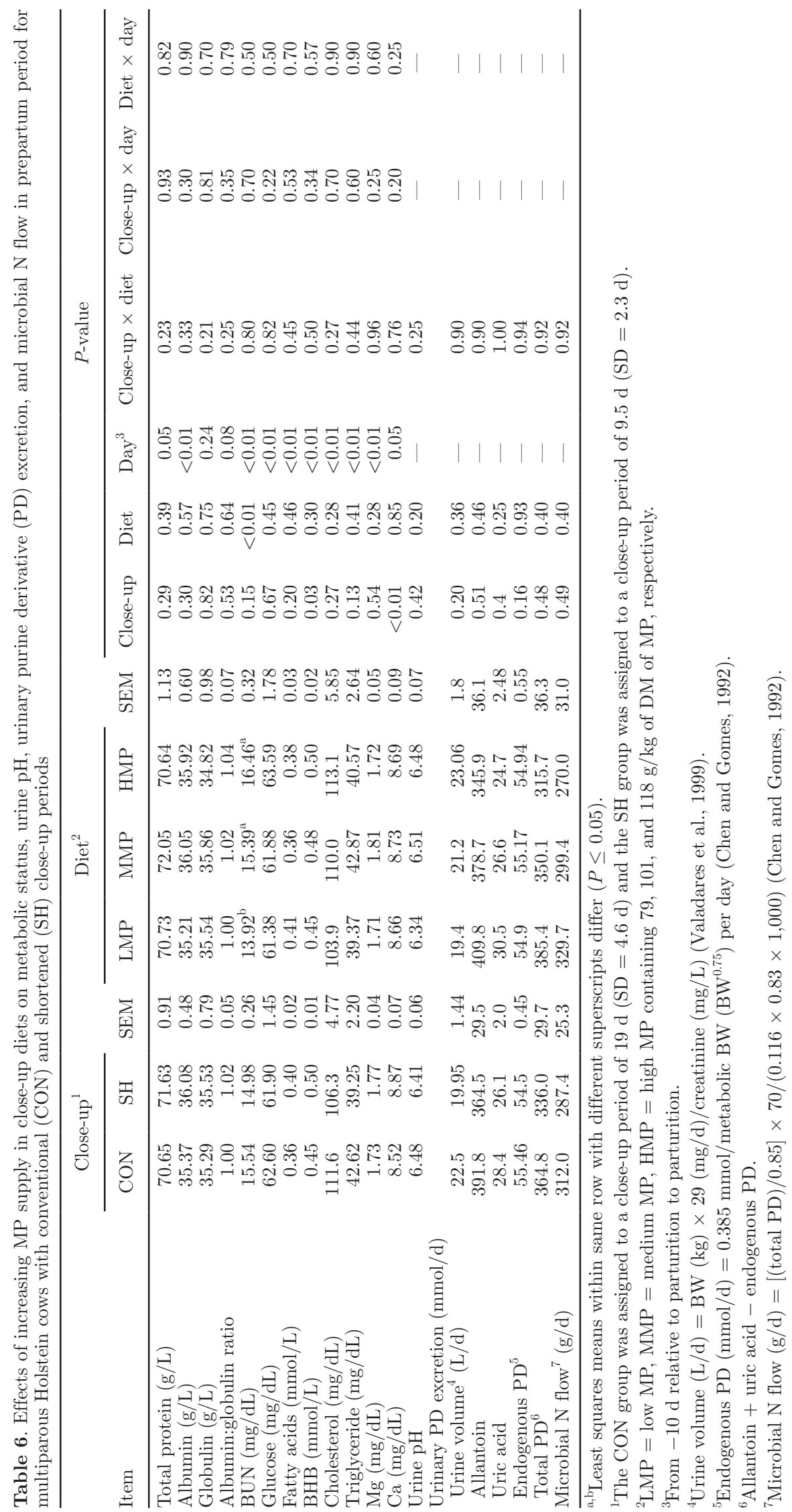


urinary acidification for cows in $\mathrm{SH}$ group receiving an anionic diet for $9.5 \pm 2.3 \mathrm{~d}$. This is supported by studies demonstrating metabolic acidosis can be induced with feeding a low DCAD diet for 4 to 5 d (Goff, 2008). Prepartum serum Ca concentration was affected $(P<$ 0.01 ) by close-up period length, with a lower level in CON group compared with SH group (Table 6). But, we did not find any effect of MP levels in the close-up diet or their interactions on prepartum Ca concentration $(P>0.10$; Table 6$)$. These results are in agreement with the findings of DeGaris et al. (2010), who reported a negative effect of increasing length of exposure to the close-up diet on prepartum Ca level. Decreased serum Ca levels could be due to greater urinary loss of Ca with longer exposure to DCAD diets, increased Ca loss in colostrum, or increased mineral demands by the fetal-placental tissue to support the observed higher birth weight $(\sim 1.5 \mathrm{~kg})$ in the CON group. Prepartum serum $\mathrm{Mg}$ was not affected by close-up period length, MP levels in close-up diet, or their interactions $(P>$ 0.10; Table 6). In agreement with our findings, DeGaris et al. (2010) observed similar Mg concentrations independent of days of exposure to the close-up diet. In addition, we found no effect of diet on urinary excretion of allantoin, uric acid, and purine derivatives (allantoin + uric acid). Microbial $\mathrm{N}$ flow estimated from purine derivatives $(P>0.10$; Table 6$)$ was not influenced by diet, which suggests decreasing dietary NFC levels from 43 to $37.8 \%$ DM in close-up diets does not compromise rumen microbial $\mathrm{CP}$ yield under the conditions of this study.

\section{Postpartum Period (1 to 21 DIM)}

$D M I, E B, B W$, and $B C S$. We found no interaction of close-up period length by levels of MP in closeup diet for DMI, net energy intake, energy balance, BW, and BCS $(P>0.10$; Table 7). Although close-up period length did not affect intakes of DM and energy $(P>0.10$; Table 7; Figure 1B), cows in the $\mathrm{SH}$ group tended to have higher EB than cows in CON group ( $P$ $=0.10$; Table 7 ). In agreement with our findings, Mann et al. (2015) found that removal of the close-up diet associated with feeding a high-fiber, controlled-energy diet during the whole dry period improved energy balance postpartum, even though postpartum DMI and milk production across treatments were not different.

Cows in the CON group lost more BW ( -32.0 vs. $-23.2 \mathrm{~kg})$ and BCS (-0.47 vs. -0.36$)$ compared with cows in the SH group during the first $21 \mathrm{~d}$ of lactation (Table 7), which was associated with greater negative $\mathrm{EB}$ and higher serum fatty acid concentrations in CON cows. The effect of close-up period length on BCS is in contrast to a previous study (Mashek and Beede, 2001) that compared a short with long close-up period (18 vs. $37 \mathrm{~d}$ ); cows in the short group lost more BCS during the first 21 DIM compared with cows in the long group $(-1.15$ vs. $-0.95 ; P<0.01)$. In the latter experiment, cows received close-up diets for more days than our study, which may explain inconsistent results.

Levels of MP in the close-up diet had significant carryover effects on some variables measured during the fresh period. The MMP and HMP diets increased postpartum DMI and EB $(P<0.01$; Table 7$)$ compared with LMP diet, but BW and BCS changes did not differ across diets $(P>0.10$; Table 7$)$. According to the hepatic oxidation theory (Allen et al., 2009), feed intake during the transition period is likely controlled predominantly by hepatic oxidation of fuels (fatty acids, propionate, glycerol, lactate, and AA). Increasing the rate of lipolysis coupled with greater supply of fatty acids to the liver at transition likely decreases DMI due to fatty acid oxidation (Allen and Piantoni, 2013). Thus, increased DMI with increasing dietary MP levels might be explained by decreased postpartum serum fatty acid concentrations or lower NFC content in our study. It has also been shown that postpartum DMI and milk yield are correlated positively to prepartum intake (Grummer, 1995; Hristov et al., 2002; Mashek and Grummer, 2003). In the current experiment, increasing dietary protein content for late gestation dairy cows improved both pre- and postpartum DMI. These results are in contrast to previous reports where DMI was similar between dietary protein treatments (Huyler et al., 1999; Vandehaar et al., 1999; Park et al., 2002). Some previous reports (Greenfield et al., 2000; Hartwell et al., 2000) also found that increasing dietary CP from 12 to $16 \%$ of DM in prepartum diets by processed soybean meal inclusion decreased postpartum DMI. Therefore, part of the observed inconsistencies across studies may be due to differences in level and source of protein, duration of supplementation, and composition of basal diet.

Milk Production and Composition. With the exception of yield of $4 \%$ FCM and content and yield of milk fat, close-up period length did not affect any of lactation variables (Table 7). Compared with SH group cows, cows in the CON group tended to have higher $4 \%$ FCM yield (36.10 vs. $34.93 \mathrm{~kg} / \mathrm{d} ; P=0.10)$ and had a higher milk fat content and yield (3.74 vs. $3.52 \%$ and 1.39 vs. $1.31 \mathrm{~kg} / \mathrm{d} ; P<0.05$ ) in the first 21 DIM (Table 7). Mashek and Beede (2001) fed cows a standard closeup diet for an average of either 18 or $37 \mathrm{~d}$ prepartum. They found no effect of time length of feeding the prepartum diet on milk yield and composition during the first 60 DIM. Another study (Contreras et al., 2004) reported feeding a close-up diet for a longer period of time (60 vs. 21 d) did not improve milk production, 
FARAHANI ET AL.

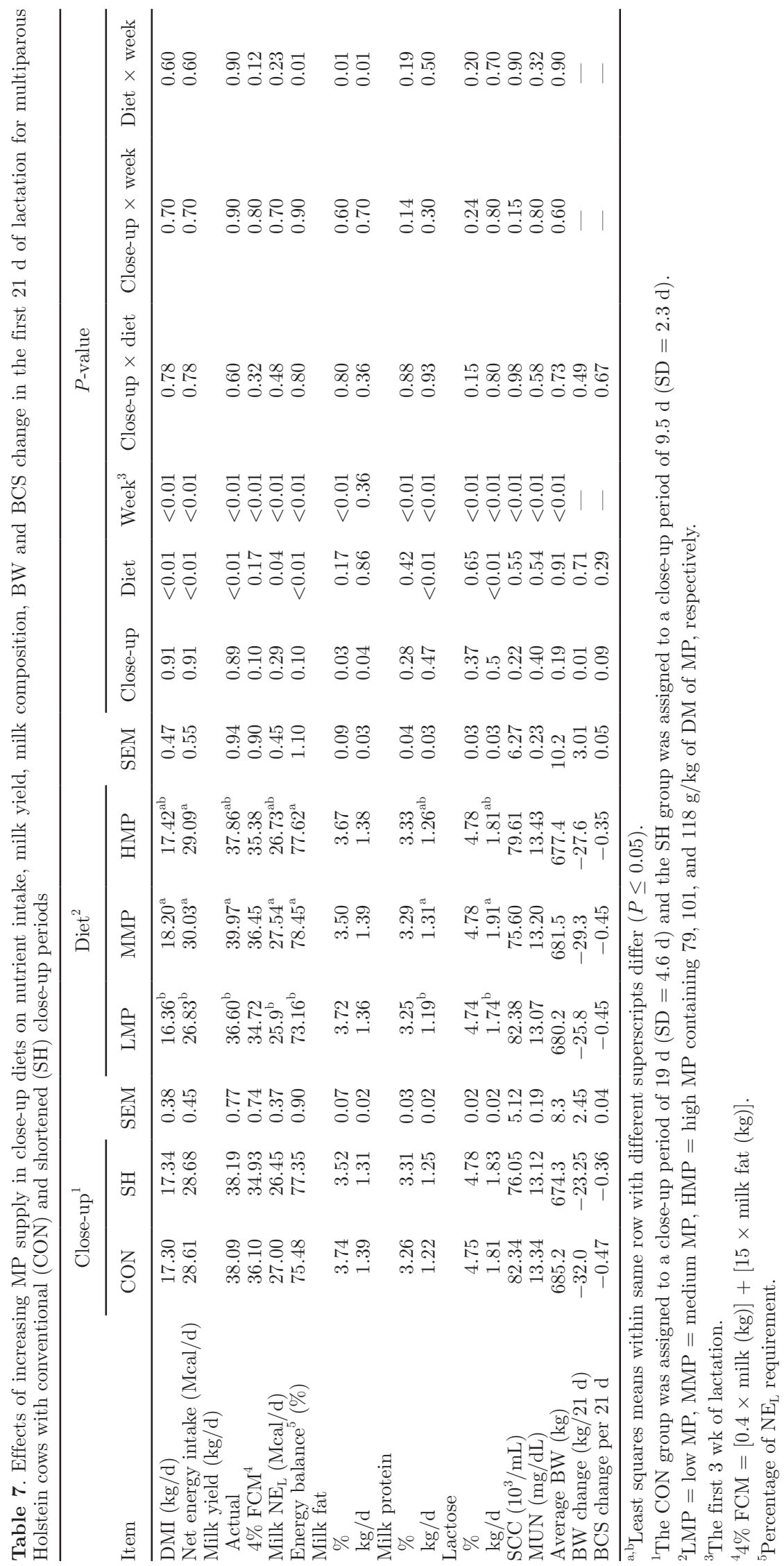


but tended to decrease milk fat content and 3.5\% FCM yield during the first 5 mo postpartum.

Some studies (Richards, 2011; Mann et al., 2015) found that a 3-wk period of close-up feeding had no beneficial effect on milk yield, but milk fat content was increased compared with feeding a far-off diet for the entire dry period, which is in agreement with our findings. Similarly, Robinson et al. (2001) reported that milk production or reproduction factors in multiparous cows were not affected by close-up period length, and optimal close-up length for primiparous cows was 9 to 12 d. In addition, DeGaris et al. (2004) compared 0 to 10,11 to 20 , and more than $20 \mathrm{~d}$ exposure to closeup diets and indicated milk yield and composition did not differ between 0 to 10 and 11 to $20 \mathrm{~d}$ groups, but increasing days of exposure to close-up diet $(>20 \mathrm{~d}$ ) led to improved milk yield and decreased milk fat content. Although, in our study, 4\% FCM yield was increased in the CON group relative to the $\mathrm{SH}$ group, higher milk fat content in fresh cows probably reflects extensive body fat mobilization and, hence, greater risk of metabolic disorders (Palmquist et al., 1993; Richards, 2011). These results are supported by lower energy balance, greater BCS loss, and higher serum fatty acid and BHB concentrations during the first 21 DIM in CON cows.

Milk yield was higher in cows fed MMP diet than cows fed LMP $(P<0.01$; Table 7$)$, but neither was different from HMP diet (37.86 vs. 36.60 and $39.97 \mathrm{~kg} / \mathrm{d}$; Table 7). Yield of $4 \%$ FCM was not influenced by diets $(P=0.17$; Table 7$)$.

Different results have been reported for effects of increasing prepartum protein on productive performance of multiparous cows. Some studies reported higher milk yield with the high-CP diets compared with the low-CP diets (Huyler et al., 1999; Phillips et al., 2003), whereas more reports observed no effect (Vandehaar et al., 1999; Robinson et al., 2001; Santos et al., 2001; Doepel et al., 2002) or even a reduction in milk production by increasing prepartum protein (Greenfield et al., 2000; Hartwell et al., 2000).

In all studies in which a positive lactation response to prepartum supplementation of protein was not observed, the postpartum diet contained $\geq 180 \mathrm{~g}$ of $\mathrm{CP} / \mathrm{kg}$ of DM. Higher postpartum dietary CP may cover the effect of protein inadequacy of prepartum diets (Bell et al., 2000). In the present study, the lactation diet contained $160 \mathrm{~g}$ of $\mathrm{CP} / \mathrm{kg}$ of $\mathrm{DM}$; the increased milk yield by increasing protein in close-up diet agrees with several earlier studies (Chew et al., 1984; Sahlu et al., 1995) in which protein level of fresh diet was less than or equal to $160 \mathrm{~g}$ of $\mathrm{CP} / \mathrm{kg}$ of $\mathrm{DM}$. Unlike the results of mentioned studies, diets with higher protein level increased prepartum DMI in our study, and higher DMI prepartum results in increased DMI and milk yield postpartum.

Milk fat, protein, and lactose content were not affected by diets $(P>0.10$; Table 7$)$. Milk fat yield did not differ across diets, but yield of milk protein and lactose were higher on MMP diet than LMP and HMP diets $(P<0.01$; Table 7$)$, which was in agreement with increased milk yield. We noted a MP $\times$ week interaction for milk fat content and yield $(P=0.01$; Table 7; Figure 2), as cows fed LMP diet maintained high milk fat content up to wk 2 after calving and decreased thereafter; in cows fed MMP and HMP, however, milk fat content decreased as DIM increased. We observed no diet effects on MUN $(P=0.30$; Table 7$)$ or SCC $(P=0.55$; Table 7$)$. Similarly, other studies found no effect of prepartum protein feeding on milk fat, protein, and lactose content (Greenfield et al., 2000; Robinson et al., 2001; Park et al., 2002; Phillips et al., 2003), MUN (Greenfield et al., 2000; Park et al., 2002; Phillips et al., 2003), and SCC (Vandehaar et al., 1999; Hartwell et al., 2000; Santos et al., 2001). The week effect was significant $(P<0.01$; Table 7$)$ for all of lactation variables, except for the yield of milk fat $(P=0.35$; Table 7).

Blood Metabolites. We found no interaction $(P>$ 0.10; Table 8) between close-up period length and levels of MP in the close-up diet for blood metabolites, except for postpartum serum fatty acid $(P=0.01$; Figure 3$)$ and BHB $(P=0.04$; Figure 4$)$ concentrations. Cows fed

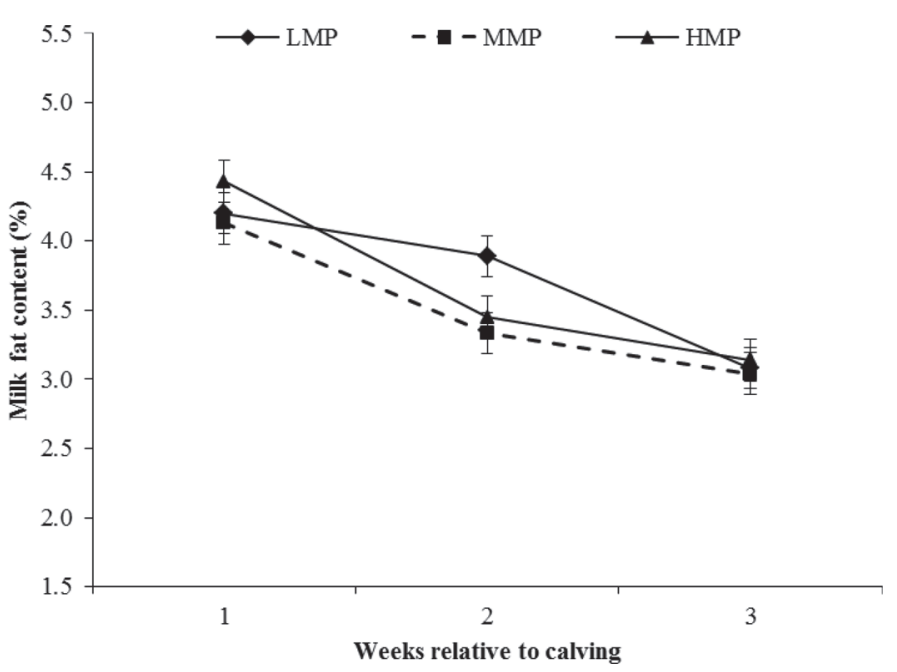

Figure 2. Effects of different MP levels in close-up diets on milk fat content of dairy cows during postpartum period (1 to 21 DIM). $\mathrm{LMP}=$ low $\mathrm{MP}, \mathrm{MMP}=$ medium $\mathrm{MP}, \mathrm{HMP}=$ high $\mathrm{MP}$ containing 79,101 , and $118 \mathrm{~g} / \mathrm{kg}$ of DM of MP, respectively. Data are presented as least squares means and SEM. Close-up, $P=0.03$; diet, $P=0.17$; week, $P<0.01$; close-up $\times$ diet, $P=0.80$; close-up $\times$ week, $P=0.60$; diet $\times$ week, $P=0.01$. 
MMP and HMP diets had lower fatty acid concentration than cows fed LMP diet in SH group $(0.80,0.53$, and $0.44 \mathrm{mmol} / \mathrm{L}$ in LMP, MMP, and HMP, respectively), but any effect of MP levels were not observed in CON group. Close-up period length did not affect $(P>$ 0.10) serum total protein, albumin, albumin-to-globulin ratio, and BUN concentrations during the first 21 DIM $(P>0.10$; Table 8$)$; however, cows in SH group tended to have lower $(P=0.10)$ globulin concentration than cows in group CON (Table 8). Globulin is known as a positive acute phase protein and its liver synthesis is commonly increased during the inflammatory condition (Bertoni et al., 2008). Our data suggest that higher globulin concentrations in the CON group than the $\mathrm{SH}$ group may be associated with some degree of inflammation. This finding is supported by increased serum fatty acids in CON group (Table 8), which results in liver dysfunction and inflammation due to more processing of fatty acids (Loor et al., 2007; Bertoni et al., 2008).

Concentrations of serum fatty acids $(P<0.01)$ and BHB $(P<0.01)$ were decreased by shortening the close-up period length (Table 8), but glucose, cholesterol, and triglycerides were similar between the 2 groups $(P>0.10 ;$ Table 8$)$. Decreased serum fatty acid and $\mathrm{BHB}$ concentrations in the $\mathrm{SH}$ group was likely a result of decreased mobilization of body fat because of differences in BCS changes ( -0.36 vs. -0.47 ; Table 6 )

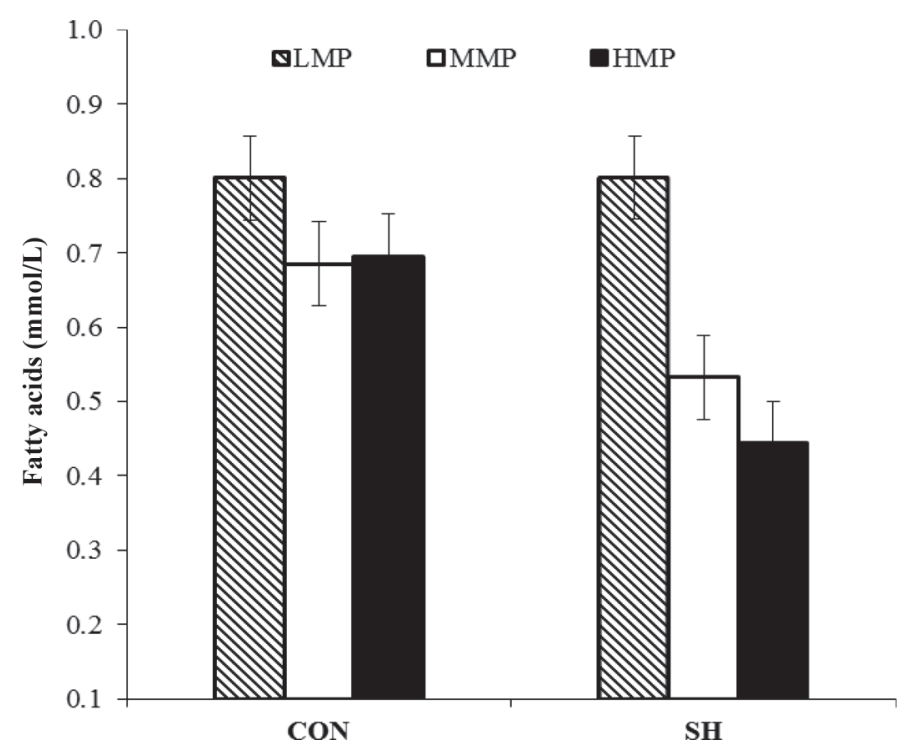

Figure 3. Effects of different MP levels in close-up diets on serum fatty acids concentrations in the first $21 \mathrm{~d}$ of lactation for dairy cows with conventional $(\mathrm{CON}, 19 \pm 4.6 \mathrm{~d})$ and shortened $(\mathrm{SH}, 9.5 \pm 2.3 \mathrm{~d})$ close-up periods. $\mathrm{LMP}=$ low MP, MMP $=$ medium $\mathrm{MP}, \mathrm{HMP}=$ high MP containing 79,101 , and $118 \mathrm{~g} / \mathrm{kg}$ of DM of MP, respectively. Data are presented as least squares means and SEM. Close-up, $P<0.01$; diet, $P<0.01$; day, $P<0.01$; close-up $\times$ diet, $P=0.01$; close-up $\times$ day, $P=0.25$; diet $\times$ day, $P=0.32$.

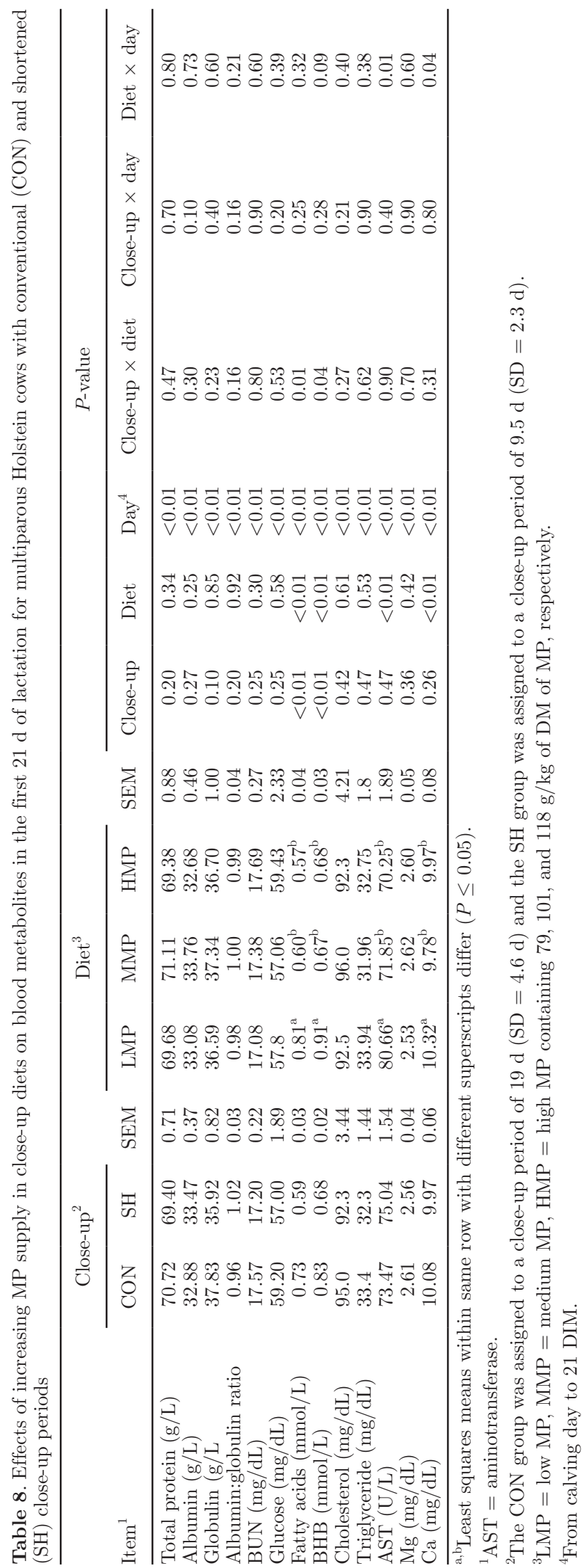




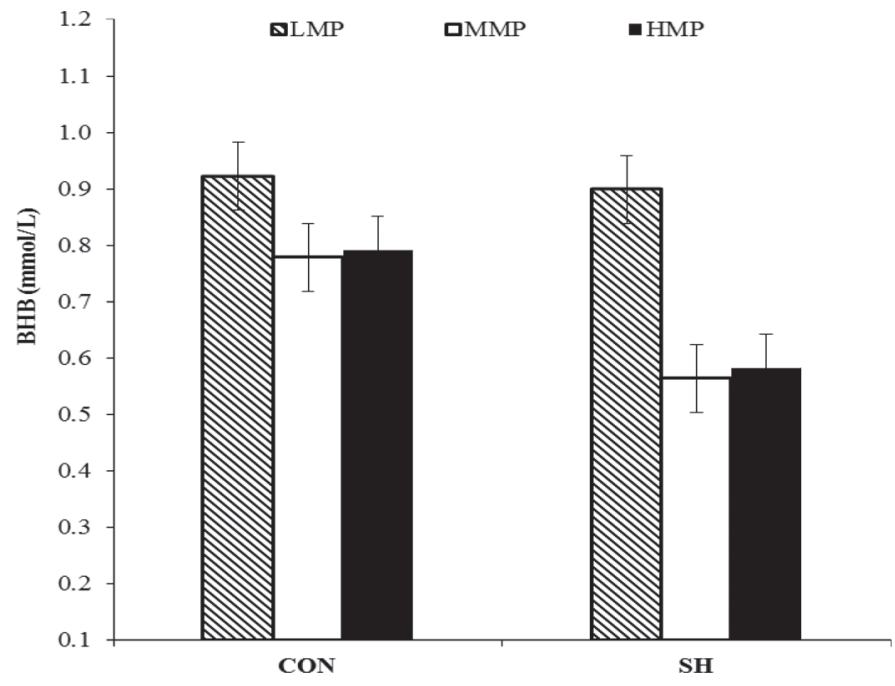

Figure 4. Effects of different MP levels in close-up diets on BHB concentrations in the first $21 \mathrm{~d}$ of lactation for dairy cows with conventional $(\mathrm{CON}, 19 \pm 4.6 \mathrm{~d})$ and shortened $(\mathrm{SH}, 9.5 \pm 2.3 \mathrm{~d})$ close-up periods. $\mathrm{LMP}=$ low $\mathrm{MP}, \mathrm{MMP}=$ medium $\mathrm{MP}, \mathrm{HMP}=$ high $\mathrm{MP}$ containing 79,101 , and $118 \mathrm{~g} / \mathrm{kg}$ of DM of MP, respectively. Data are presented as least squares means and SEM. Close-up, $P<0.01$; diet, $P<0.01$; day, $P<0.01$; close-up $\times$ diet, $P=0.04$; close-up $\times$ day, $P$ $=0.28$; diet $\times$ day, $P=0.09$.

between the $\mathrm{SH}$ and $\mathrm{CON}$ groups. These results are not consistent with Mashek and Beede (2001), who reported higher plasma fatty acid concentration (542.4 vs. $487.1 \mu \mathrm{Eq} / \mathrm{L}$ ) for cows in a short compared with long close-up period. The length of feeding the close-up diet in their experiment was substantially longer than the close-up time used in the current study, which may explain the obtained results. Two studies (Richards, 2011; Mann et al., 2015) elicited similar concentrations of fatty acids and BHB for cows fed a far-off diet over whole dry period ( 1 group) and for those fed a 2-stage (far-off and close-up) diet, but having a close-up period in the 2-stage treatment increased subclinical ketosis incidence during the postpartum period in latter study.

During the postpartum period, concentrations of both serum fatty acids and BHB were decreased by increasing protein levels in close-up diet (Table 8). An $\mathrm{MP} \times$ day interaction also existed for serum BHB $(P$ $=0.09$; Figure 5). Cows fed the LMP diet had higher BHB concentrations than cows on the MMP and HMP diets. The concentration of BHB peaked at 3 DIM for cows on LMP diet, whereas it peaked at $\mathrm{d} 7$ postpartum for cows on MMP and HMP diets.

Contrary to our findings, others (Huyler et al., 1999; Greenfield et al., 2000; Hartwell et al., 2000; Santos et al., 2001; Park et al., 2002; Phillips et al., 2003) reported no effect of prepartum protein level on postpartum fatty acid and BHB concentrations. In these studies, feeding high-protein diets during the close-up period had no positive carryover effects on postpartum DMI. Again, a lack of observed effects may be the result of differences in dietary MP or RUP delivery and AA content of MP; however, lower serum fatty acid and BHB concentrations in cows fed MMP and HMP diets compared with cows fed LMP diet was associated with increased DM and $\mathrm{NE}_{\mathrm{L}}$ intakes and improved $\mathrm{EB}$ in our study, which subsequently reduced fat mobilization. Holtenius and Hjort (1990) reported lower fatty acid concentration and fatty liver score for cows fed a higher protein prepartum diet, which is in agreement with our finding. Similarly, previous studies evaluating ketosis incidence after supplementation of protein in prepartum diets reported a significant reduction in ketosis incidence when cows received RUP sources in prepartum period (Curtis et al., 1985; Van Saun and Sniffen, 1995). Van Saun (1993) also reported that clinical ketosis prevalence was lower for cows fed $1,300 \mathrm{~g} / \mathrm{d}$ of MP than for cows fed $1,100 \mathrm{~g} / \mathrm{d}$ of MP over the prepartum period, which is consistent with the metabolic responses observed in the current study for a similar dietary MP range.

Serum AST activity was influenced $(P<0.01)$ by MP levels in the close-up diet, with a lower concentration in MMP and HMP cows compared with LMP cows (Table 8). Also, the MP $\times$ day interactions were significant for AST (Figure 6), as cows fed the LMP diet had higher AST concentrations compared with cows fed MMP and HMP diets at 3,14 , and 21 DIM. This finding might be explained by elevated serum fatty acid concentrations

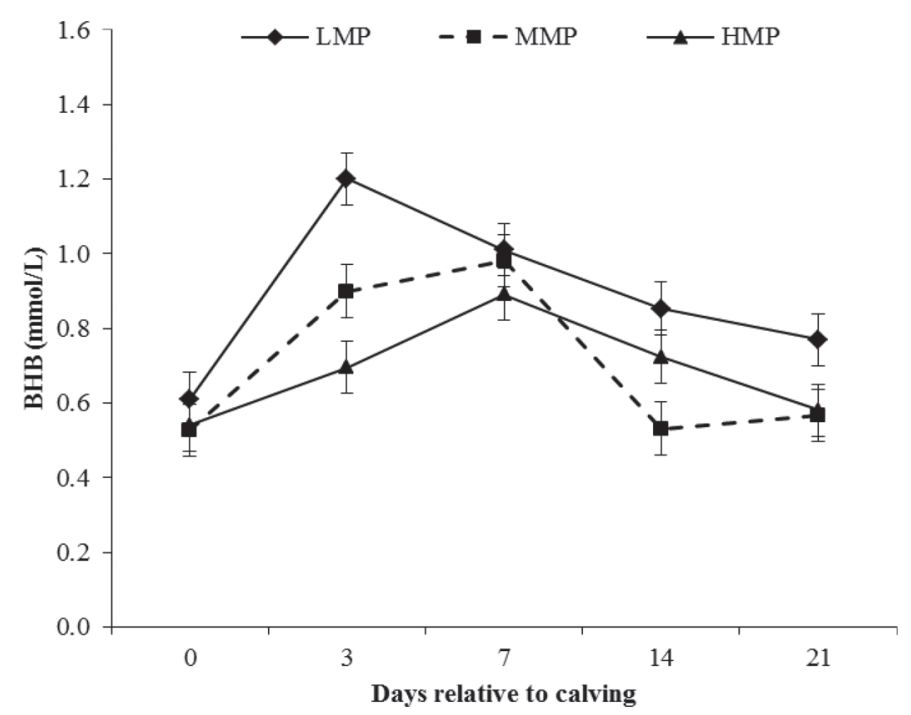

Figure 5. Effects of different MP levels in close-up diets on BHB concentrations of dairy cows during postpartum period (1 to 21 DIM). $\mathrm{LMP}=$ low MP, MMP = medium MP, HMP = high MP containing 79,101 , and $118 \mathrm{~g} / \mathrm{kg}$ of DM of MP, respectively. Data are presented as least squares means and SEM. Close-up, $P<0.01$; diet, $P<0.01$; day, $P<0.01$; close-up $\times$ diet, $P=0.23$; close-up $\times$ day, $P=0.28$; diet $\times$ day, $P=0.09$. 
influencing liver function, or the elevated AST might be attributed to greater muscle protein mobilization. Chamberlin et al. (2013) and Djoković et al. (2013) revealed a positive correlation between plasma fatty acid concentration and AST activity. When plasma fatty acid concentration increases, the infiltration of fat into liver leads to hepatocyte destruction and enzyme activity, indicating liver damage (e.g., AST) is increased (Lubojacka et al., 2005; Stojević et al., 2005). The elevated concentrations of serum fatty acids for LMP cows rather than for MMP and HMP cows may explain increased AST activity in the present study (Table 8; Figure 6). Thus, from the perspective of metabolic and liver function, increasing protein level in the close-up diets has no harmful effects on liver health in cows immediately after calving. In agreement with our findings, Park et al. (2002) reported that postpartum AST concentration decreased linearly in response to prepartum dietary protein. Likewise, AST activity can reflect muscle damage that may reflect increased skeletal muscle degradation in the face of inadequate dietary AA supply. Providing additional dietary protein prepartum may reduce postpartum mobilization of skeletal muscle.

Postpartum, no interaction between close-up period length and MP level in the close-up diet was detected for serum mineral status $(P>0.10$; Table 8$)$. Serum $\mathrm{Mg}$ concentration was not affected by close-up period length or MP levels in the close-up $\operatorname{diet}(P>0.10$; Ta-

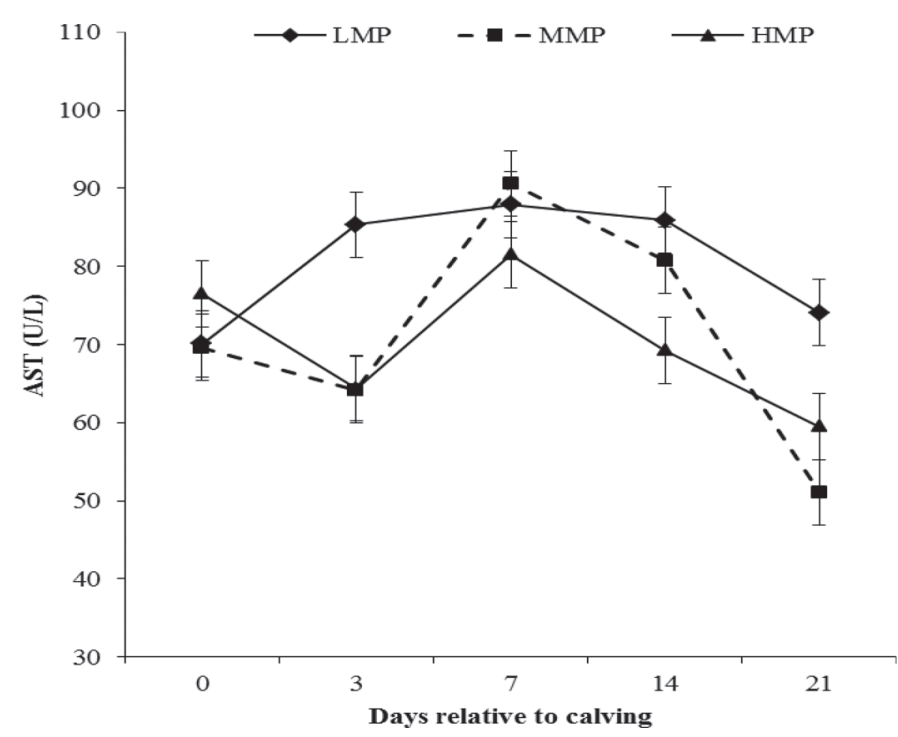

Figure 6. Effects of different MP levels in close-up diets on aminotransferase (AST) concentrations of dairy cows during postpartum period $(1$ to $21 \mathrm{DIM}) . \mathrm{LMP}=$ low $\mathrm{MP}, \mathrm{MMP}=$ medium $\mathrm{MP}, \mathrm{HMP}=$ high MP containing 79, 101, and $118 \mathrm{~g} / \mathrm{kg}$ of DM of MP, respectively. Data are presented as least squares means and SEM. Close-up, $P=$ 0.47 ; diet, $P<0.01$; day, $P<0.01$; close-up $\times$ diet, $P=0.90$; close-up $\times$ day, $P=0.40$; diet $\times$ day, $P<0.01$.

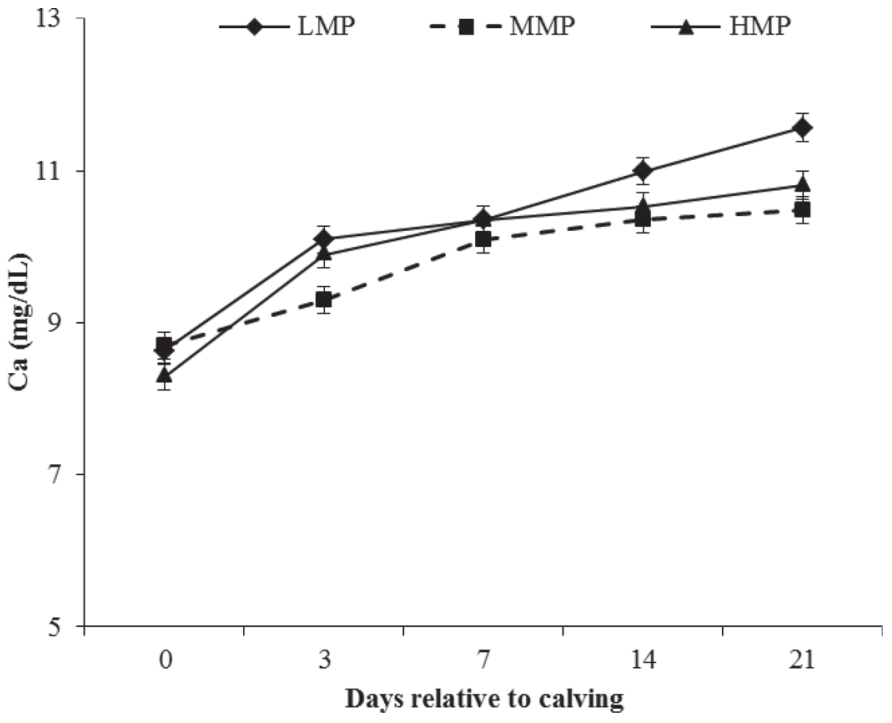

Figure 7. Effects of different MP levels in close-up diets on Ca concentrations of dairy cows during postpartum period (1 to 21 DIM). $\mathrm{LMP}=$ low MP, MMP = medium MP, HMP = high MP containing 79,101 , and $118 \mathrm{~g} / \mathrm{kg}$ of DM of MP, respectively. Data are presented as least squares means and SEM. Close-up, $P=0.26$; diet, $P<0.01$; day, $P<0.01$; close-up $\times$ diet, $P=0.31$; close-up $\times$ day, $P=0.80$; diet $\times$ day, $P=0.04$.

ble 8). Serum Ca concentrations were similar between $\mathrm{CON}$ and $\mathrm{SH}$ groups $(P=0.26$; Table 8$)$, but average Ca concentration reduced with feeding a higher protein level in the close-up diet $(P<0.01$; Table 8; Figure $7)$. This reduction can be attributed to the significant increase in milk yield during the postpartum period for cows fed MMP and HMP diets versus LMP diet, which is caused by greater output of Ca in milk (Table 7). This effect may be consistent with the findings of Jawor et al. (2012), who reported an inverse relationship between serum calcium status and milk production during the first $28 \mathrm{~d}$ of lactation.

\section{Health Disorders}

The incidence of health disorders were recorded daily and reported as the number of cows with at least one incidence (Table 9). No cases of retained placenta, milk fever, clinical ketosis, and displaced abomasum were observed during the experiment. The incidences of hypocalcemia (serum $\mathrm{Ca} \leq 8.5 \mathrm{mg} / \mathrm{dL}$ ) were 7 and 6 events in the CON and $\mathrm{SH}$ groups, respectively; with 5, 3 , and 5 cases for LMP, MMP, and HMP, respectively. Ten cows were diagnosed with hypomagnesemia (serum $\mathrm{Mg}<1.7 \mathrm{mg} / \mathrm{dL} ; 5,3$, and 2 cases for LMP, MMP, and HMP, respectively). The incidences of subclinical ketosis (BHB $\geq 1.2 \mathrm{mmol} / \mathrm{L}$ ) were 7 and 5 events in CON and SH groups, respectively; with 6,3 , and 3 cases for LMP, MMP, and HMP, respectively. However, health 
Table 9. Effects of increasing MP supply in close-up diets on health disorders for multiparous Holstein cows with conventional $(\mathrm{CON})$ and shortened $(\mathrm{SH})$ close-up periods ${ }^{1}$

\begin{tabular}{|c|c|c|c|c|c|}
\hline \multirow[b]{2}{*}{ Health disorder } & \multicolumn{2}{|c|}{ Close-up ${ }^{2}$} & \multicolumn{3}{|c|}{ Diet $^{3}$} \\
\hline & $\mathrm{CON}$ & $\mathrm{SH}$ & LMP & MMP & HMP \\
\hline Dystocia & 2 & 1 & 0 & 1 & 2 \\
\hline Retained placenta & 0 & 0 & 0 & 0 & 0 \\
\hline Milk fever & 0 & 0 & 0 & 0 & 0 \\
\hline Hypocalcemia $^{4}$ & 7 & 6 & 5 & 3 & 5 \\
\hline Hypomagnesemia $^{5}$ & 5 & 5 & 5 & 3 & 2 \\
\hline Subclinical ketosis ${ }^{6}$ & 7 & 5 & 6 & 3 & 3 \\
\hline Clinical ketosis & 0 & 0 & 0 & 0 & 0 \\
\hline Displaced abomasum & 0 & 0 & 0 & 0 & 0 \\
\hline Mastitis & 1 & 1 & 1 & 1 & 0 \\
\hline Metritis & 2 & 2 & 1 & 1 & 2 \\
\hline Endometritis & 2 & 2 & 2 & 1 & 1 \\
\hline \multicolumn{6}{|c|}{${ }^{1}$ Number of cows with at least one incidence. } \\
\hline $\begin{array}{l}{ }^{2} \text { The CON group was } \\
\text { close-up period of } 9.5 \\
{ }^{3} \mathrm{LMP}=\text { low MP, MM } \\
\text { respectively. } \\
{ }^{4} \text { Serum Ca concentrati } \\
{ }^{5} \text { Serum Mg concentrati } \\
{ }^{6} \text { Serum BHB } \geq 1.2 \mathrm{~mm}\end{array}$ & $\begin{array}{l}\text {-up per } \\
\text { HMP } \\
\text { calving } \\
\text { calving }\end{array}$ & $19 \mathrm{~d}$ & $\begin{array}{l}\text { d) and } \\
79,10\end{array}$ & $\begin{array}{l}\text { group } \\
118 \mathrm{~g} /\end{array}$ & $\begin{array}{l}\text { signed } t \\
M \text { of } \mathrm{I}\end{array}$ \\
\hline
\end{tabular}

data should be interpreted with caution because of the limited sample size in our study.

\section{CONCLUSIONS}

Shortening close-up period length improved EB and decreased fatty acid and BHB concentrations postpartum, but had no effect on pre- and postpartum DMI and milk yield. The MMP and HMP diets increased prepartum DMI, and cows fed MMP had higher DMI and milk yield than those fed the LMP diet postpartum. The levels of MP in the close-up diet did not affect any of prepartum blood metabolites, except for BUN concentration, whereas the concentrations of postpartum fatty acids, BHB, AST, and Ca were decreased by increasing MP levels in the close-up diet. In conclusion, our results suggest that multiparous cows will benefit from a shortened close-up period, and feeding a moderate-MP diet during the close-up period could improve DMI, milk yield, and metabolic status of periparturient dairy cows. However, dairy producers may need to be cautious in shortening the close-up period length due to the uncertainty of calving date.

\section{ACKNOWLEDGMENTS}

This research was supported by FKA Co. (Isfahan, Iran). The authors gratefully thank J. Jalilnejad (FKA Co., Isfahan, Iran) for facilitating the present study and his financial support. The authors acknowledge farm veterinarians and experts for their invaluable assistance in conducting this experiment. In particular, we thank Robert Van Saun (Department of Veterinary and Biomedical Sciences, University Park, Pennsylvania State University) for his invaluable comments on this paper, and Najme Eslamian Farsuni (Department of Animal Sciences, University of Zanjan) for her help in conducting this experiment.

\section{REFERENCES}

Adachi, N., T. Kusuhara, I. Nonaka, and F. Terada. 2006. Effect of close-up dry period protein level on preparturiental nitrogen balance and lactating performance of primigravid and multiparous Holstein cows. Asian-Aust. J. Anim. Sci. 19:831-836.

Allen, M. S. 2000. Effects of diet on short-term regulation of feed intake by lactating dairy cattle. J. Dairy Sci. 83:1598-1624.

Allen, M. S., B. J. Bradford, and M. Oba. 2009. The hepatic oxidation theory of the control of feed intake and its application to ruminants. J. Anim. Sci. 87:3317-3334.

Allen, M. S., and P. Piantoni. 2013. Metabolic control of feed intake: Implications for metabolic disease of fresh cows. Vet. Clin. North Am. Food Anim. Pract. 29:279-297.

Amanlou, H., A. P. Akbari, N. E. Farsuni, and N. Silva-del-Rio. 2016. Effects of subcutaneous calcium administration at calving on mineral status, health, and production of Holstein cows. J. Dairy Sci. 99:9199-9210.

Amanlou, H., T. Amirabadi Farahani, and N. Eslamian Farsuni. 2017. Effects of rumen undegradable protein supplementation on productive performance and indicators of protein and energy metabolism in Holstein fresh cows. J. Dairy Sci. 100:3628-3640.

AOAC. 1990. Official Methods of Analysis. 15th ed. Association of Official Analytical Chemists, Arlington, VA.

Bell, A. W. 1995. Regulation of organic nutrient metabolism during transition from late pregnancy to early lactation. J. Anim. Sci. 73:2804-2819

Bell, A. W., W. S. Burhans, and T. R. Overton. 2000. Protein nutrition in late pregnancy, maternal protein reserves and lactation performance in dairy cows. Proc. Nutr. Soc. 59:119-126. 
Bertoni, G., E. Trevisi, X. Han, and M. Bionaz. 2008. Effects of inflammatory conditions on liver activity in puerperium period and consequences for performance in dairy cows. J. Dairy Sci. 91:33003310 .

Chamberlin, W. G., J. Middleton, J. Spain, G. Johnson, M. Ellersieck, and P. Pithua. 2013. Subclinical hypocalcemia, plasma biochemical parameters, lipid metabolism, postpartum disease, and fertility in postparturient dairy cows. J. Dairy Sci. 96:7001-7013.

Chen, X. B., and M. Gomes. 1992. Estimation of microbial protein supply to sheep and cattle based on urinary excretion of purine derivatives-an overview of the technical details. Pages 1-23 in Int. Feed Res. Unit, Occasional Publ. Rowett Research Institute, Aberdeen, UK

Chew, B. P., F. Murdock, R. Riley, and J. Hillers. 1984. Influence of prepartum dietary crude protein on growth hormone, insulin, reproduction, and lactation of dairy cows. J. Dairy Sci. 67:270-275.

Contreras, L. L., C. Ryan, and T. Overton. 2004. Effects of dry cow grouping strategy and prepartum body condition score on performance and health of transition dairy cows. J. Dairy Sci. 87:517523.

Corbett, R. 2002. Influence of days fed a close-up dry cow ration and heat stress on subsequent milk production in western dairy herds. J. Dairy Sci. 85(Suppl 1):191-192.

Curtis, C. R., H. N. Erb, C. J. Sniffen, R. D. Smith, and D. S. Kronfeld. 1985. Path analysis of dry period nutrition, postpartum metabolic and reproductive disorders, and mastitis in Holstein cows. J. Dairy Sci. 68:2347-2360.

Dann, H. M., N. Litherland, J. Underwood, M. Bionaz, A. D'angelo, J. McFadden, and J. Drackley. 2006. Diets during far-off and closeup dry periods affect periparturient metabolism and lactation in multiparous cows. J. Dairy Sci. 89:3563-3577.

DeGaris, P. J., I. Lean, A. Rabiee, and C. Heuer. 2008. Effects of increasing days of exposure to prepartum transition diets on milk production and milk composition in dairy cows. Aust. Vet. J. $86: 341-351$.

DeGaris, P. J., I. Lean, A. Rabiee, and C. Heuer. 2010. Effects of increasing days of exposure to prepartum transition diets on reproduction and health in dairy cows. Aust. Vet. J. 88:84-92.

DeGaris, P. J., I. J. Lean, D. M. McNeil, and A. R. Rabiee. 2004 Effects of increased exposure to precalving diets containing BIOCHLOR: Milk production. J. Dairy Sci. 87(suppl. 1):439.

Djoković, R., V. Kurćubić, Z. Ilić, M. Cincović, M. Petrović, N. Fratrić, and B. Jašović. 2013. Evaluation of metabolic status in Simmental dairy cows during late pregnancy and early lactation. Vet. Arh. 83:593-602.

Doepel, L., H. Lapierre, and J. Kennelly. 2002. Peripartum performance and metabolism of dairy cows in response to prepartum energy and protein intake. J. Dairy Sci. 85:2315-2334.

Douglas, G. N., T. Overton, H. Bateman, H. Dann, and J. Drackley. 2006. Prepartal plane of nutrition, regardless of dietary energy source, affects periparturient metabolism and dry matter intake in Holstein cows. J. Dairy Sci. 89:2141-2157.

Edmonson, A., I. Lean, L. Weaver, T. Farver, and G. Webster. 1989. A body condition scoring chart for Holstein dairy cows. J. Dairy Sci. 72:68-78.

Emery, R. S. 1993. Energy needs of dry cows. Pages 35-42 in Proc. Tri-State Dairy Nutr. Conf. Ft. Wayne, IN. Ohio Coop. Ext. Serv. Columbus.

Goff, J. P. 2008. Transition cow immune function and interaction with metabolic diseases. Pages $45-57$ in in Proc. 17th Annu. Tri-State Dairy Nutr. Conf., Fort Wayne, IN. M. Eastridge, ed. The Ohio State University, Columbus.

Greenfield, R. B., M. Cecava, T. Johnson, and S. Donkin. 2000. Impact of dietary protein amount and rumen undegradability on intake, peripartum liver triglyceride, plasma metabolites, and milk production in transition dairy cattle. J. Dairy Sci. 83:703-710.

Grummer, R. R. 1995. Impact of changes in organic nutrient metabolism on feeding the transition dairy cow. J. Anim. Sci. 73:28202833
Grummer, R. R., D. G. Mashek, and A. Hayirli. 2004. Dry matter intake and energy balance in the transition period. Vet. Clin. North Am. Food Anim. Pract. 20:447-470.

Hartwell, J. R., M. Cecava, and S. Donkin. 2000. Impact of dietary rumen undegradable protein and rumen-protected choline on intake, peripartum liver triacylglyceride, plasma metabolites and milk production in transition dairy cows. J. Dairy Sci. 83:2907-2917.

Hayirli, A., R. Grummer, E. Nordheim, and P. Crump. 2002. Animal and dietary factors affecting feed intake during the prefresh transition period in Holsteins. J. Dairy Sci. 85:3430-3443.

Holtenius, P., and M. Hjort. 1990. Studies on the pathogenesis of fatty liver in cows. Bov. Pract. 25:91-94.

Hook, T. E., K. G. Odde, A. A. Aguilar, and J. D. Olson. 1989. Protein effects on fetal growth, colostrum and calf immunoglobulins and lactation in dairy heifers. J. Anim. Sci. 67(Suppl. 1):539-539.

Hristov, A., W. Price, and B. Shafii. 2002. Dietary factors influencing milk yield and milk protein yield in dairy cows. Pages 147-166 in Proc. Pacific Northwest Animal Nutr. Conf., Vancouver, British Columbia, Canada. C R Press, Portland, OR.

Huyler, M. T., R. Kincaid, and D. Dostal. 1999. Metabolic and yield responses of multiparous Holstein cows to prepartum rumen-undegradable protein. J. Dairy Sci. 82:527-536.

Janovick, N. A., Y. Boisclair, and J. Drackley. 2011. Prepartum dietary energy intake affects metabolism and health during the periparturient period in primiparous and multiparous Holstein cows. J. Dairy Sci. 94:1385-1400.

Jawor, P. E., J. Huzzey, S. LeBlanc, and M. von Keyserlingk. 2012. Associations of subclinical hypocalcemia at calving with milk yield, and feeding, drinking, and standing behaviors around parturition in Holstein cows. J. Dairy Sci. 95:1240-1248.

Jonker, J. S., R. Kohn, and R. Erdman. 1998. Using milk urea nitrogen to predict nitrogen excretion and utilization efficiency in lactating dairy cows. J. Dairy Sci. 81:2681-2692.

Lean, I. J., P. DeGaris, D. McNeil, and E. Block. 2006. Hypocalcemia in dairy cows: Meta-analysis and dietary cation anion difference theory revisited. J. Dairy Sci. 89:669-684.

Lean, I. J., R. Van Saun, and P. J. DeGaris. 2013. Energy and protein nutrition management of transition dairy cows. Vet. Clin. North Am. Food Anim. Pract. 29:337-366.

Lee, C., A. Hristov, K. Heyler, T. Cassidy, H. Lapierre, G. Varga and C. Parys. 2012. Effects of metabolizable protein supply and amino acid supplementation on nitrogen utilization, milk production, and ammonia emissions from manure in dairy cows. J. Dairy Sci. 95:5253-5268.

Littell, R. C., P. Henry, and C. Ammerman. 1998. Statistical analysis of repeated measures data using SAS procedures. J. Anim. Sci. $76: 1216-1231$

Loor, J. J., R. E. Everts, M. Bionaz, H. M. Dann, D. E. Morin, R. Oliveira, S. L. Rodriguez-Zas, J. K. Drackley, and H. A. Lewin. 2007. Nutrition-induced ketosis alters metabolic and signaling gene networks in liver of periparturient dairy cows. Physiol. Genomics 32:105-116.

Lubojacka, V., A. Pechova, R. Dvořák, P. Drastich, V. Kummer, and J. Poul. 2005. Liver steatosis following supplementation with fat in dairy cow diets. Acta Vet. Brno 74:217-224.

Mann, S., F. L. Yepes, T. Overton, J. Wakshlag, A. Lock, C. Ryan, and D. Nydam. 2015. Dry period plane of energy: Effects on feed intake, energy balance, milk production, and composition in transition dairy cows. J. Dairy Sci. 98:3366-3382.

Marquardt, J. P., R. Horst, and N. Jorgensen. 1977. Effect of parity on dry matter intake at parturition in dairy cattle. J. Dairy Sci. 60:929-934.

Mashek, D. G., and D. Beede. 2001. Peripartum responses of dairy cows fed energy-dense diets for 3 or 6 weeks prepartum. J. Dairy Sci. 84:115-125.

Mashek, D. G., and R. Grummer. 2003. Effects of long chain fatty acids on lipid and glucose metabolism in monolayer cultures of bovine hepatocytes. J. Dairy Sci. 86:2390-2396.

NRC. 2001. Nutrient Requirements of Dairy Cattle, 7th rev. ed., Natl. Acad. Press, Washington, DC. 
Ospina, P. A., D. Nydam, T. Stokol, and T. Overton. 2010. Evaluation of nonesterified fatty acids and $\beta$-hydroxybutyrate in transition dairy cattle in the northeastern United States: Critical thresholds for prediction of clinical diseases. J. Dairy Sci. 93:546-554.

Overton, T., and M. Waldron. 2004. Nutritional management of transition dairy cows: Strategies to optimize metabolic health. J. Dairy Sci. 87:E105-E119.

Palmquist, D. L., A. D. Beaulieu, and D. Barbano. 1993. Feed and animal factors influencing milk fat composition. J. Dairy Sci. 76:1753-1771.

Park, A. F., J. Shirley, E. Titgemeyer, M. Meyer, M. VanBaale, and M. VandeHaar. 2002. Effect of protein level in prepartum diets on metabolism and performance of dairy cows. J. Dairy Sci. 85:18151828.

Phillips, G. J., T. Citron, J. Sage, K. Cummins, M. Cecava, and J. McNamara. 2003. Adaptations in body muscle and fat in transition dairy cattle fed differing amounts of protein and methionine hydroxy analog. J. Dairy Sci. 86:3634-3647.

Rabelo, E., R. Rezende, S. Bertics, and R. Grummer. 2003. Effects of transition diets varying in dietary energy density on lactation performance and ruminal parameters of dairy cows. J. Dairy Sci. 86:916-925.

Richards, B. F. 2011. Strategies to decrease incidence of fatty liver in dairy cows. PhD thesis. Dept. Anim. Sci., Univ. Illinois, Urbana.

Robinson, P. H., J. Moorby, M. Arana, R. Hinders, T. Graham, L. Castelanelli, and N. Barney. 2001. Influence of close-up dry period protein supplementation on productive and reproductive performance of Holstein cows in their subsequent lactation. J. Dairy Sci. 84:2273-2283.

Roche, J. R., S. Meier, A. Heiser, M. Mitchell, C. Walker, M. Crookenden, M. V. Riboni, J. Loor, and J. Kay. 2015. Effects of precalving body condition score and prepartum feeding level on production, reproduction, and health parameters in pasture-based transition dairy cows. J. Dairy Sci. 98:7164-7182.

Sahlu, T., S. Hart, T. Le-Trong, Z. Jia, L. Dawson, T. Gipson, and T. Teh. 1995. Influence of prepartum protein and energy concentrations for dairy goats during pregnancy and early lactation. J. Dairy Sci. 78:378-387.

Santos, F. A. P., J. E. P. Santos, C. B. Theurer, and J. T. Huber. 1998. Effects of rumen undegradable protein on dairy cow performance: A 12-year literature review. J. Dairy Sci. 81:3182-3213.
Santos, J. E., E. DePeters, P. Jardon, and J. Huber. 2001. Effect of prepartum dietary protein level on performance of primigravid and multiparous Holstein dairy cows. J. Dairy Sci. 84:213-224.

Stojević, Z., J. Piršljin, S. Milinković-Tur, M. Zdelar-Tuk, and B. B. Ljubić. 2005. Activities of AST, ALT and GGT in clinically healthy dairy cows during lactation and in the dry period. Vet. Arh. 75:67-73.

Valadares, R. F., G. Broderick, S. Valadares Filho, and M. Clayton. 1999. Effect of replacing alfalfa silage with high moisture corn on ruminal protein synthesis estimated from excretion of total purine derivatives. J. Dairy Sci. 82:2686-2696.

Van Saun, R. J. 1993. Effects of undegradable protein fed prepartum on subsequent lactation, reproduction, and health in Holstein dairy cattle. PhD thesis. Dept. Anim. Sci., Cornell University, Ithaca, NY.

Van Saun, R. J., and C. J. Sniffen. 1995. Effects of undegradable protein fed prepartum on lactation, reproduction, and health in dairy cattle. II. Postpartum diets and performance. J. Dairy Sci. 78(Suppl. 1):265.

Van Soest, P. J., J. Robertson, and B. Lewis. 1991. Methods for dietary fiber, neutral detergent fiber, and nonstarch polysaccharides in relation to animal nutrition. J. Dairy Sci. 74:3583-3597.

Vandehaar, M. J., G. Yousif, B. Sharma, T. Herdt, R. Emery, M. Allen, and J. Liesman. 1999. Effect of energy and protein density of prepartum diets on fat and protein metabolism of dairy cattle in the periparturient period. J. Dairy Sci. 82:1282-1295.

Vickers, L. A., D. Weary, D. Veira, and M. von Keyserlingk. 2013. Feeding a higher forage diet prepartum decreases incidences of subclinical ketosis in transition dairy cows. J. Anim. Sci. 91:886894

Young, E. G., and C. F. Conway. 1942. On the estimation of allantoin by the Rimini-Schryver reaction. J. Biol. Chem. 142:839-853.

Zhang, Q., H. Su, F. Wang, Z. Cao, and S. Li. 2015. Effects of energy density in close-up diets and postpartum supplementation of extruded full-fat soybean on lactation performance and metabolic and hormonal status of dairy cows. J. Dairy Sci. 98:7115-7130. 